\title{
Mitochondrial donation in translational medicine; from imagination to reality
}

\author{
Hesam Saghaei Bagheri ${ }^{1,3}$, Farhad Bani ${ }^{2}$, Savas Tasoglu ${ }^{3,4}$, Amir Zarebkohan $^{2}$, Reza Rahbarghazi ${ }^{5,6^{*}}$ (D) \\ and Emel Sokullu ${ }^{1,3^{*}}$
}

\begin{abstract}
The existence of active crosstalk between cells in a paracrine and juxtacrine manner dictates specific activity under physiological and pathological conditions. Upon juxtacrine interaction between the cells, various types of signaling molecules and organelles are regularly transmitted in response to changes in the microenvironment. To date, it has been well-established that numerous parallel cellular mechanisms participate in the mitochondrial transfer to modulate metabolic needs in the target cells. Since the conception of stem cells activity in the restoration of tissues' function, it has been elucidated that these cells possess a unique capacity to deliver the mitochondrial package to the juxtaposed cells. The existence of mitochondrial donation potentiates the capacity of modulation in the distinct cells to achieve better therapeutic effects. This review article aims to scrutinize the current knowledge regarding the stem cell's mitochondrial transfer capacity and their regenerative potential.
\end{abstract}

Keywords: Stem cells, Mitochondrial transfer, Cellular mechanisms, Regenerative potential

\section{Background}

The discovery of stem cells has revolutionized human medicine and these cells are touted as a promising therapeutic modality in the alleviation of different injuries [1]. During past decades, several clinical trials using multiple stem cells, especially MSCs, provide alternative therapeutic approaches to replace injured cells with the functional cells [2]. Compared to other stem cells, MSCs are easily accessible from mesenchymal tissues and could be produced in large scales for point-of-care delivery [3]. Meanwhile, the bio-preservation of MSCs has minimal potency loss and karyotypic abnormalities compared to adult somatic cells and other stem cell types [4]. Due to the lack of comprehensive understanding related to MSCs mechanism of action, further investigations are

\footnotetext{
*Correspondence: rezarahbardvm@gmail.com; rahbarghazir@tbzmed.ac.ir esokullu@ku.edu.tr; emelsu@gmail.com

${ }^{1}$ School of Medicine, Biophysics Department, Koç University, Rumeli Fener, Sarıyer, Istanbul, Turkey

${ }^{5}$ Stem Cell Research Center, Tabriz University of Medical Sciences, Tabriz, Iran

Full list of author information is available at the end of the article
}

highly demanded to address the quantity and quality of therapeutic effects driven by MSCs after transplantation into the target sites. Up to date, it has been shown that these cells accelerate the repair of injured areas via engaging different underlying activities such as differentiation into distinct cell lineage, the release of arrays of cytokines and growth factors, and the promotion of cellto-cell connection [5]. Rapid advances in the field of stem cell biology help us to discover very special restorative approaches used by stem cells to return the function of target cells after exposure to the insulting agents. In this regard, it has been well-documented that the transfer of mitochondrial from MSCs to acceptor cells is an important endogenous regeneration mechanism in the context of tissue regeneration [6]. Despite significant signs of progress in the elucidation of mitochondrial donation, the distinct mechanisms and critical factors involved in this process have not been fully discovered. Here, in this review article, we focused on the potency of stem cells, especially MSCs, to donate mitochondria to the non-stem cells under pathological conditions. In addition to an important role of mitochondria in stem cell 
(See figure on next page.)

Fig. 1 Mitochondria act as a powerhouse of the cell (a). Metabolic pathways within mitochondria contribute to molecular biosynthesis and the production of ATP. Inside mitochondrial, pyruvate, fatty acids, and amino acids were oxidized and electrons enter to electron transport chain. The production of ATP is facilitated by an electrochemical gradient through oxidative phosphorylation. The role of mitochondria during differentiation (b).The size and number of mitochondria are increased in stem cells along with maturation to the mature cell types. In the progress of differentiation, mitochondria are elongated and the length of crista increase because of active oxidative phosphorylation. It seems that reactive oxygen species and oxygen radicals increase by activation of mitochondrial function. Carnitine palmitoyltransferase I, II: CPT I and II; Cytochrome c: CytC; Flavin adenine dinucleotide: FADH; Nicotinamide adenine dinucleotide: NADH; Reactive oxygen species: ROS; Tricarboxylic acid: TCA; Uncoupling proteins: UCPS

differentiation, different intracellular machinery involved in the mitochondrial donation were also reviewed. It seems that these data will help us to understand the potency of stem cells, mainly MSCs, in the restoration of injured tissues via mitochondrial donation.

\section{The role of mitochondria in cell metabolism}

Metabolism is the complex of vital chemical reactions inside single organisms [7]. This process includes food conversion to energy in response to the energy demands by synthesizing blocks for proteins, lipids, nucleic acids, and carbohydrates; and the elimination of nitrogenous wastes. With the promotion of cell metabolism, various intermediate factors are interchanged between the cells in a tightly regulated manner [8]. Both catabolic and anabolic metabolic reactions are tightly regulated under physiological conditions. As a common belief, different forms of cellular metabolism depend on redox reactions that involve the transfer of electrons from reduced donor molecules such as organic molecules, water, ammonia, hydrogen sulfide or ferrous ions to acceptor molecules such as oxygen, nitrate or sulfate [9]. In this regard, the mitochondrion, as a major source of cellular energy, has a key role in the promotion of catabolic and anabolic reactions. Interestingly, the number of mitochondria differs based on cell type and cell growth stage [10]. For instance, erythrocytes are devoid of mitochondria, whereas hepatocytes have more than 2000 mitochondria per each cell [11].

\section{Mitochondrion ultrastructure}

The mitochondrion contains outer and inner membranes composed of phospholipid bilayers and proteins. The outer membrane, encompassing the entire mitochondrial space, has a thickness of $60-75 \AA$. The protein/ phospholipid ratio in the outer membrane is similar to that of the eukaryotic cell membrane. A large number of integral membrane proteins, termed porins, are present in the outer membrane. An inter-membrane space exists between the outer and inner layers, which is also termed peri-mitochondrial space. Due to the permeability of the outer membrane to small-size biomolecules, the concentration of ions and small polysaccharides in both sides of the outer membrane is the same. There are functional proteins in the inner membrane that make this layer eligible for cellular bioactivity. According to previously published data [12, 13], several functional proteins are integrated into the inner membrane. These proteins participate in the redox reaction chain of oxidative phosphorylation; synthesis of ATP in the mitochondrial matrix; transportation of specific molecules inside and outside of mitochondrial matrix; and mitochondrial fusion and fission.

\section{Mitochondrial metabolism}

Oxidative phosphorylation is touted as the main biochemical reaction required for the production of cellular energy and is considered as a powerhouse. Oxidative phosphorylation is governed by coordinated cascades of redox reactions via protein complexes located in the inner mitochondrial membrane, which is known as the electron transport chain complex (Fig. 1a). Inside the mitochondrial matrix, enzymes related to the tricarboxylic acid (ETC) cycle provide electron transporters such as nicotinamide adenine dinucleotide (NADH) and flavin adenine dinucleotide $\left(\mathrm{FADH}_{2}\right)$ [14]. This collection consists of I-IV protein complexes, soluble factors, cytochrome $\mathrm{C}$ oxidase, and coenzyme $\mathrm{Q}$ which deliver electrons to the ETC.

Complex I and II transfer two electrons from the electron carriers (NADH/FADH2) to the coenzyme Q. Complex III is an adaptor effector that uptakes two electrons from the reduced form of coenzyme $Q$ and subsequently transfers electrons to cytochrome $\mathrm{C}$ oxidase (Fig. 1a). Complex IV interrupts the respiratory chain after the transfer of electrons from cytochrome $\mathrm{C}$ oxidase by the reduction of oxygen to produce water [15, 16]. The unique reduction/oxidation reactions contribute to conformational changes in ETC of respiratory complexes, enabling mitochondria to force protons out of the matrix and transfer to the inter-membrane space. These activities generate an electrochemical gradient which is called the mitochondrial transmembrane potential $(\Delta \Psi)$. The collection of I, III, and IV units generates a proton 


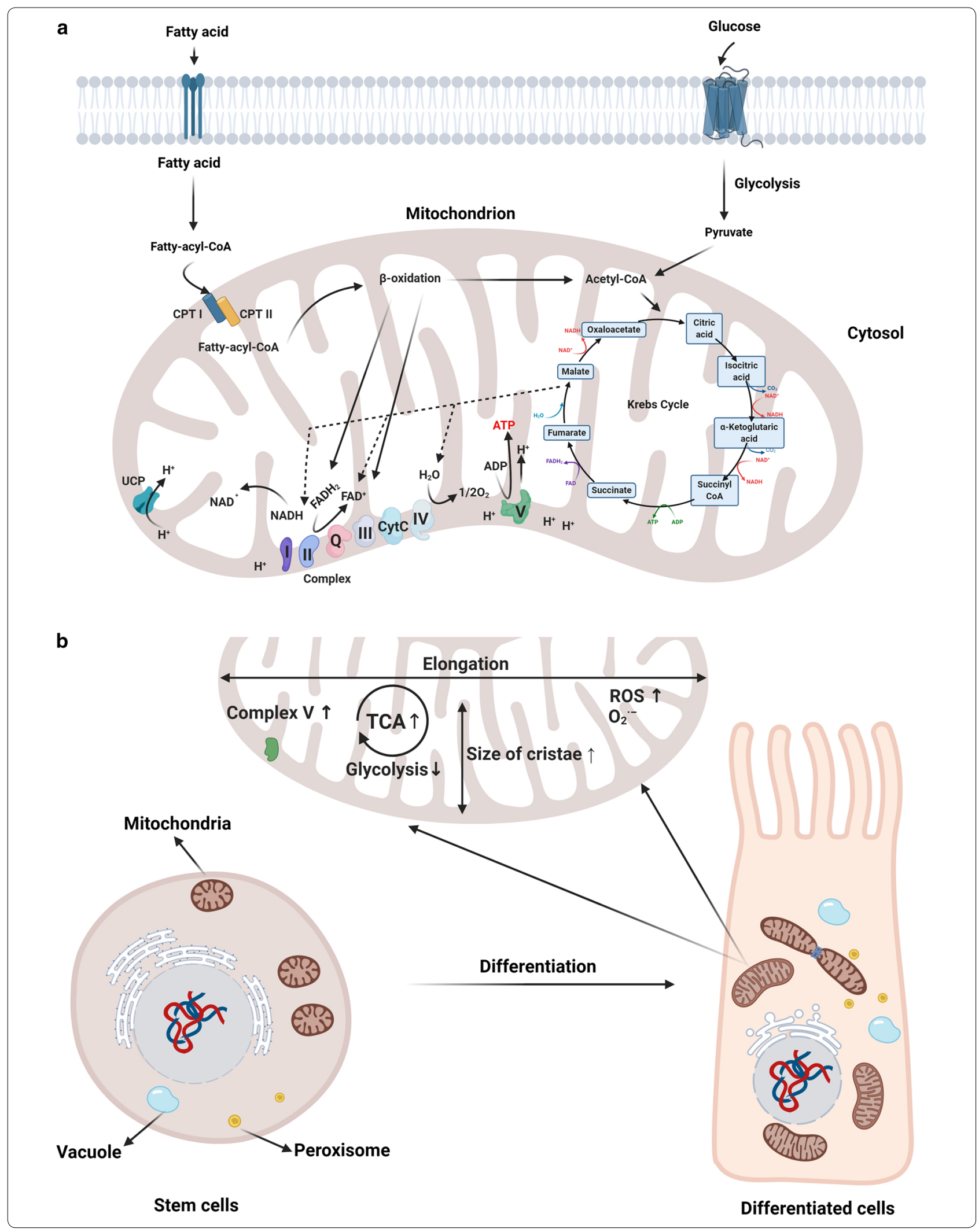


drive force via an ATP synthase Complex V that converts adenosine diphosphate to adenosine triphosphates [16]. The transportation of proteins and carbohydrates across the inner mitochondrial membrane can influence the trans-membrane potential [17]. During the electron transport, these elements may leak and react with oxygen to produce superoxide anion that participates in the formation of reactive oxygen species (ROS). In this regard, complexes I and III are the main producers in the accumulation of ROS inside the cells, although some reports showed the potency of Complex II in ROS production [18-20]. TCA is located inside the mitochondrial matrix and is composed of a series of enzyme-catalyzed chemical reactions during aerobic respiration. All lipids, carbohydrates, or proteins contribute to the production of intermediate metabolites that incorporate with TCA to oxide carbon molecules into $\mathrm{CO}_{2}$ and produce energy. Most of the metabolites interact with TCA via Acetyl-CoA in distinct manners. To initiate the TCA cycle, pyruvate is transported into the matrix of mitochondria to oxidize and react with the Coenzyme A, producing Acetyl-CoA. In an alternative pathway, pyruvate can also be carboxylated to form oxaloacetate, a critical member of the TCA. During fatty acid metabolism, the $\beta$-oxidation reaction is initiated. Long-chain fatty acids are metabolized in multiple stages to ultimately constitute Acetyl-CoA. For the metabolism of proteins, glutamine is further catabolized to produce glutamate, which is by itself transformed into $\alpha$-ketoglutarate [21].

In addition to the mitochondrial role on catabolic reactions, these micro-sized particles also participate in the biosynthesis of proteins, lipids, and carbohydrates. In this regard, intermediate metabolites produced by the TCA can leave the mitochondria and subsequently can be consumed as blocks for the synthesis of numerous macromolecules. It is believed that the TCA maintains its activity by procedures which are through replenishment of intermediates via a mechanism called anaplerosis [21]. Commensurate with these comments, mitochondria per se regulate the intracellular contents of amino acids and co-factors required for the functional activity of multiple enzymes, particularly DNA modifying enzymes such as histone deacetylases. The ability to maintain ionic dynamics at physiological levels could dictate the tightly regulated dynamic of ketogenesis, lipogenesis, steroidogenesis, gluconeogenesis, and ammonium detoxification $[22,23]$.

\section{The role of mitochondria in cell differentiation}

Differentiation is the dynamic cellular process where an unspecific cell is committed to a specific lineage [24]. In general, differentiation encompasses changes in metabolome, genetic pattern, and proteome during a definite period. It is believed that this process is initiated from the formation of the zygote to the end of life, enabling cells to acquire specific function and phenotype [25]. Differentiation is a tightly controlled modification at the molecular levels involving methylation of specific genes, modulation of expression, and protein synthesis. Such processes need regulated energy consumption according to their adaptation to novel conditions [26, 27]. From the genetic perspective, primary and differentiated cells are the same but with different cellular functions and properties in response to extracellular signals. The existence of a steady-state and immortal energy source such as the mitochondrion could facilitate these adaptations. Not only the number and bioactivity of the mitochondria pool have a pivotal role in the promotion of differentiation, but also, the dynamics and morphology of this organelle are changed along with maturation. Other experiments also highlighted the subcellular localization of mitochondria in stem cells committed to distinct cells [28]. It has been elucidated that the maturation of myoblasts to mature myocytes after treatment with TGF- $\beta$ increased respiration capacity coincided with changes in protein composition of mitochondria [29]. In this regard, the content of complex IV protein MTCO1 was significantly suppressed in the mature myocytes [29]. Noteworthy, it is well established that mitochondria are randomly scattered in the oocyte from different species meanwhile a peri-pronuclear localization of mitochondria has been observed after fertilization. Overall, not only mitochondrial number/function is critical in developmental stages but also change in subcellular clustering occurs with maturation and aging [30]. Another reason for this change would be that cell resistance to insulting conditions will be decreased by maturation due to the accumulation of oxidative stress and aged organelles occurring along with the increase of cell passage and division (Fig. 1b). To circumvent these conditions, the number of mitochondria is increased to neutralize the detrimental effects of free radicals [28, 31, 32]. A series of experiments reported that free radicals act as an antagonist to prohibit cell differentiation toward cardiovascular lineage [33, 34]. It is perhaps not surprising that mitochondrial metabolism is a regulator of the differentiation of stem cells toward cardiovascular lineage [35]. Of course, the issue becomes more complicated by the opposite result. Calling attention, it has been shown that the existence of mitochondria is beneficial to maintain the stemness feature in certain lineages. In this regard, several markers, in particular, nestin are integral to neural progenitor cells multipotentiality is affected by mitochondrial activity [36].

Odontoblastic differentiation of dental progenitor cells requires cellular activity which is related to increased extracellular mineralization, alkaline phosphatase 
function, and the expression of specific protein such as dentin, sialophosphoproteins, etc. The phenotype acquisition is promoted when the content of adenosine- $5^{\prime}-$ triphosphate is elevated. To afford biochemical demands, the mitochondrial potential is induced to correct the $\mathrm{NAD}^{+} / \mathrm{NADH}$ ratio and detoxify the free reactive oxygen ions. In support of this claim, the suppression of mitochondrial respiration by inhibitor rotenone decreases the odontogenic differentiation capacity [37]. Pouyafar and co-workers found that the inhibition of lipolysis by chemical inhibitor, namely TOFA, suppressed the endothelial differentiation and expression of VE-cadherin in human cancer stem cells [38]. Interestingly, they also found that the treatment of cancer $\mathrm{CD} 133^{+}$cells with Lonidamine, an inhibition of aerobic glycolysis, promoted differentiation endothelial differentiation [38]. Regarding the high basal metabolic rate and necessity for additional energy sources, it is noteworthy to mention that mitochondrial mass and ultrastructural adaptations are mandatory for efficient cell maturation and differentiation.

\section{Intercellular mitochondrial transfer}

A body of documents stands for a fact that mitochondrial transfer actively occurs between cells from distinct types to other lineages [39]. However, elucidation of the extent, duration, and bioactivity of transferred mitochondria in the target cells needs future investigations. For example, stem cells from connective tissues known as mesenchymal stem cells (MSCs) showed a great potential to deliver and transfer mitochondria to multiple cells residing in the specific tissues in in vitro conditions and in animal models [40]. Currently, many researchers are trying to address underlying mechanisms by which these MSCs donate mitochondria to injured cells and to increase the therapeutic outcomes of stem cell therapy by the regulation of mitochondrial transfer [41]. The main hypothesis for mitochondria transfer was provided by the existence of nanotubular structures during the active mitochondrial transfer which not only harbors mitochondrial content but also the transfer of many other cellular constituents [42]. These morphological adaptations showed the unlimited potency of mammalian cells in reciprocal mitochondrial interchange in specific niches [43, 44]. Such transfer could induce numerous underlying modalities as shown previously in in vitro or in vivo conditions. Some investigations noted the active role of mitochondrial transfer in the bioactivity of cells such as lymphocytes, neurons, or cardiomyocytes. As above-mentioned, the construction of juxtacrine interaction between cells provides a secure torrent of cellular content transfer in a unidirectional or bidirectional manner.

Indeed, a panel of distinct molecules, effectors, signaling modulators, and ions participate in the formation of unique entangled molecular networks inside and between the cells. Sometimes, these contents are packed and transferred in the form of enclosed micro- and nanosized packages such as mitochondria, lysosomes, endosomal vesicles, and other plasma membrane structures [45]. A typical example of mitochondrial transfer is referred to as the discovery of restoration of respiration capacity in mitochondria-deficient human cells [46]. Somatic cellfree mitochondria are induced by prolonged incubation with ethidium bromide and depletion of mtDNA. These cells are vulnerable and could not maintain basal metabolism in a conventional culture medium. The mitochondrial transfer can restore the aerobic respiration chain and improve cell bioactivities [46]. Liu et al. performed in vitro co-culture of MSCs with ECs under a condition similar to the ischemia-reperfusion niche. They proved the transfer and activation of MSC-derived mitochondria within the cytosol of ECs, contributing to endothelial activity in glucose- and oxygen-free medium [47]. Therefore, one could hypothesize that mitochondria transfer can promote angiogenesis and endothelial function at the site of ischemia.

In addition to an inherent capacity of stem cells to transfer mitochondrial elements to another cell type, numerous experiments showed the potency of mitochondrial transfer between immortalized cells and primary cells from the same or different species [48]. Like other cell activities, this phenomenon is associated with energy consumption and conceived as an active transfer. The formation of TNTs could be presented as the main cellular machinery of mitochondria transfer although a portion of mitochondrial structure i.e. mtDNA or mitochondrial fragments, but not whole complex, could also be transferred horizontally to target cells [48]. The main propose of mitochondrial transfer is to restore the aerobic activity of target cells with an abrogated mitochondrial activity $[6,49]$. Fortunately, the mitochondrial transfer is practically happening inside the body $[6,50]$. According to emerging data, attempts must be focused on the rate, quality, and intensity of mitochondrial transfer during various pathologies. Notably, certain specific condition like cancerous niche develops a unique medium to interchange a large number of mitochondria between cells residing close $[6,50]$. Not as a general rule, it seems that cells displaying numerous aberrancies and injuries are more permissive to mitochondria transfer compared to healthy cell counterparts [51, 52]. To maintain mitochondrial transfer, the formation of TNTs is mandatory which has been previously proved in injured human umbilical vein ECs. In the first step, spatial arrangement, location of phosphatidylserine molecules is changed in the acceptance cells. This molecule acts 
as find-me signals and promotes the formation of TNTs to maintain a juxtacrine connection with surrounding cells [47]. In contrast to cells and tissues with prodigious regeneration capacity, find-me signals are more vital in tissues without cellular replacement property, in particular the central nervous system [6]. The promotion of pro-inflammatory status following bacterial lipopolysaccharide challenge was found to enable injured pulmonary epithelial cells to fuse with human stem cells by using gap junction (connexin-43), and TNTs formation [53].

Considering the complexity of mitochondrial transfer, it is reasonable to imagine that various machinery systems take part in this phenomenon. For instance, it was demonstrated that mitochondrial transfer is promoted by a close collaboration of cytoskeletal-related factors with different effectors. Among them, a protein capable of connecting mitochondria to a cytoskeletal protein termed Miro1 accelerates the transmission of mitochondria from human MSCs to asthmatic pulmonary epithelial cells [54].

Based on the evidence, there are pros and cons correlated with the mitochondrial transfer in the context of tissue niche. As previously described, it seems that mitochondrial exchange between cancer cells could induce resistance to therapeutic modalities. Even though, the mtDNA transfer between donor cancer cells and normal neighboring cells not only can change tumor dynamics but also potentiates the metabolism shift from anaerobic to the aerobic state $[55,56]$. However, any modulations in the activity of the mtDNA source could regulate the dynamic growth of recipient cancer cells and may be a therapeutic approach in cancer biology.

The formation of TNTs is initiated with ultrastructural changes of the cell membrane and filopodial projections in which the use of relevant inhibitors prohibits cellular adaptation to release mitochondria. However, TNTs formation seems to be independent of the excretory capacity of cells. In line with this claim, the inhibition of phagocytosis, endocytosis, or exocytosis does not per se affect TNTs alignment in host cells although some overlapping mechanisms exist between these activities [57]. Using some approaches, we can promote the rate of mitochondrial transfer to the target cells. For instance, doxorubicin and hydrogen peroxide treatment, and expansion of cells in serum-free and high glucose conditions increase the transcription of apoptosis-related effectors such as p53 and Caspase 3. The activation of $\mathrm{p} 53$ promotes Caspase 3 cleavage and S100A4 degradation, participating in mitochondrial transfer and reception [58-60]. Commensurate with the above descriptions, the occurrence of pathological conditions could be touted as a stimulatory factor to circumvent mitochondria-devoid status in target cells.

\section{Cellular structures mediating intercellular mitochondrial transfer}

Although, the exact mechanism of mitochondrial transfer is not fully elucidated different hypotheses have been considered in this regard. The most common mechanisms include membrane microvesicles, cell fusion, or mitochondrial protrusion. It seems that the modulatory effect and functional behavior of transmitted mitochondria might be dependent on physiopathological situations. Even in physiological conditions, the transmission of mitochondria is not completely safe in which some reports noted immune cell recruitment and the occurrence of mitophagy (mitochondrial death) in recipient cells after exogenous mitochondria arrival. In some cases, the mitochondrial transfer coincides with the parasite and bacterial transmission, Entameba histolytica, Francisella tularensis, and Salmonella enterica from cell to cell [61, 62].

Tumor-derived mitochondria are prone to undergo mutation and alter the cellular mechanism of recipient cells [56]. It is not surprising to implicate that mitochondria transfer from normal cells to tumor cells could retrieve a basal metabolic capacity. Previous data in this field showed that bone marrow-derived mitochondria could abrogate the accelerated angiogenesis rate during tumor development [55].

Time, mitochondrial number, and route of transfer are critical to the restoration of activity in the injured cells [63]. Therefore, the application of strategic plans is mandatory in achieving successful therapeutic effects. For instance, some researchers used the Sendai virus envelope-based approach to generate micro tunnels with length sizes ranging from 4.1 to $10 \mu \mathrm{m}$. Single mitochondrial transfer contributed to homoplasmy of mitochondrial DNA in the target cells. This strategy can contribute to intelligent control of mitochondrial transfer, preventing mitochondrial accumulation in recipient cells. Although cytoplasmic elongation can form cell-to-cell physical contact, it simultaneously regulates the mitochondrial flow rate to the accepting cells. Soon after mitochondrial transfer, cell connection to neighboring cells is immediately interrupted and this feature is an indicator of a successful transmission [64].

In general, TNTs types are based on cytoskeletal architecture, size, and function. The type 1 TNTs are characterized by long and prominent cytosolic tunnels encompassing both microfilaments and microtubules while type 2 is in small size and tubulin free. Experiments showed the capacity of type 1 TNTs in mediating organelle transfer $[65,66]$. Considering the connection type, TNTs are categorized into three types namely closed, open, and gap-junction based TNTs (Fig. 2a). As abovementioned, Miro1, mitochondrial Rho GTPase 1, is 
a
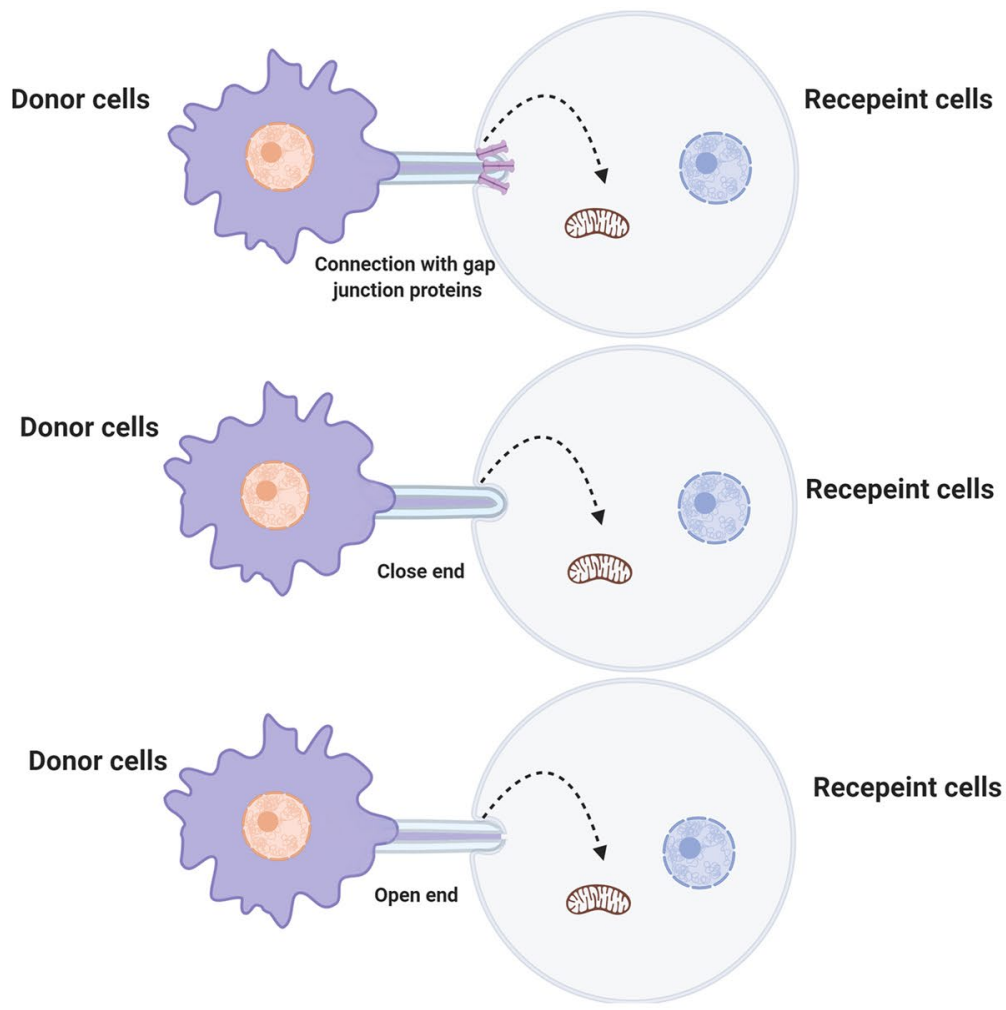

b

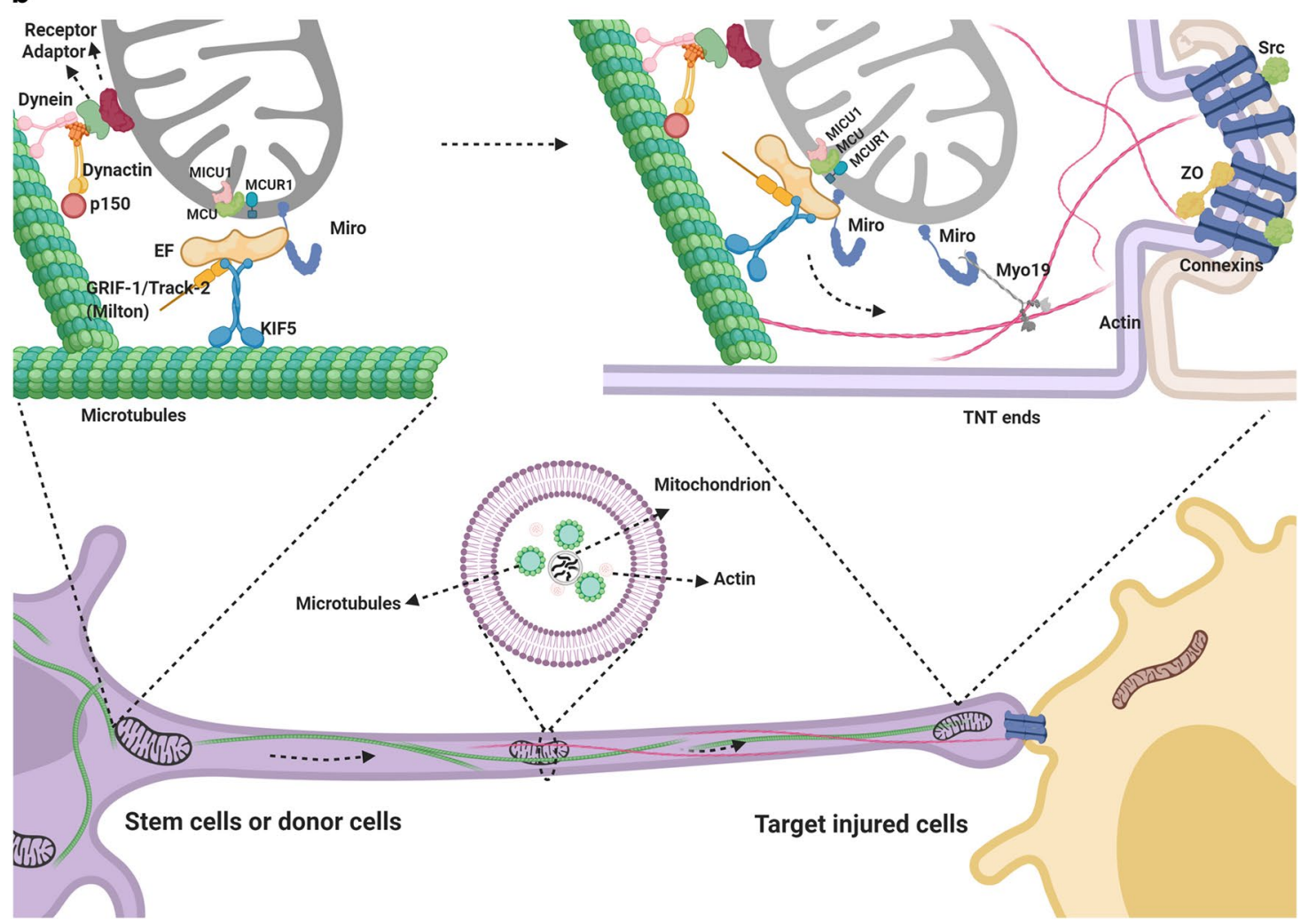

Fig. 2 The transport of mitochondria through the TNTs formed between the donor and recipient cells (a). TNT bridges are close-, open-ended, or connected to the cells via gap-junction molecules. Molecular machinery participates in the transfer of mitochondria between the cells (b) 
actively engaged in the mitochondrial trafficking between the cells. This factor is a calcium-dependent adaptor that closes mitochondria to the cytoskeletal scaffold (Fig. 2b) [54, 67]. In detail, Miro1 acts as an anchor to maintain the connection of mitochondria to the cell membrane and subsequently attached to the KIF5 kinesin motor. The modulation of intracellular calcium content is critical to dictate these changes. The use of calcium blockers is shown to prohibit the attachment of Miro1 to KIF5 kinesin motor. In the final stage, the binding of Miro1 to KIF5 kinesin motor initiates the formation of connexin 43-containing gap junction channels, making microsized tubes to orchestrate mitochondrial trafficking (Fig. 2b) [53, 68]. Interestingly, a close association of the mTOR signaling pathway with TNTs formation was previously found $[58,69]$. Therefore, it could be mentioned that the activation of the mTOR axis, as seen during apoptosis and autophagy, could also potentiate the donor and recipient cells to track mitochondria reciprocally by overexpression of trafficking adaptors such [70].

By contrast, the increase of horizontal mitochondrial transfer could be used as a regenerative treatment to boost target cell metabolism. Direct injection of mitochondrial mass [71] or transplantation of MSCs [72] within the lesion zone could favor therapeutic outcomes via the mitochondrial transfer. Selecting donor cells bearing compatible connexin combinations should maximize GJC-mediated docking efficiency. Increasing mitochondrial mass by exposure to the AMP analog AICAR or a hypoxia-reoxygenation sequence would increase the number of available organelles [73]. Eventually, TNTmediated mitochondria transfer could be stimulated either by a ROS-inducing treatment or by microtubulestabilizing strategies (e.g., with inhibitors targeting kif11/ Eg5 which acts as a 'brake' on microtubule extension [74], or by overexpression of trafficking adaptors such as Miro1 in the donor cells [75].

\section{Mitochondrial transfer in in vitro condition}

Spees et al. first demonstrated that after co-culture of lung adenocarcinoma mtDNA-deficient A549 $\rho^{\circ}$ cells with MSCs, A549 $\rho^{\circ}$ cells could uptake functional mitochondria from the MSCs [46]. Also, the isolated mitochondria from the immortalized untransformed mammary epithelial MCF-12A cells could easily enter malignant breast cancer cell lines such as MCF-7, MDAMB-231, and NCI/ADR-Res cells compared to MCF-12A lineage. Upon mitochondrial transfer, the proliferation of these cells is suppressed in a dose-dependent pattern that coincided with increased cell sensitivity to doxorubicin, Abraxane, and carboplatin [76]. Intriguingly, vascular smooth muscle cells co-cultured with MSCs induced proliferation of MSCs through mitochondrial transfer [77].
Although it has been shown that mitochondria transfer to injured cells could restore cellular function, the release of mitochondria may result in a series of immune responses. The mitochondrial components may be recognized as damage-associated molecular patterns, which induced strong pro-inflammatory reactions in the bloodstream and extracellular medium [78, 79]. For example, mtDNA released into extracellular space induces Toll-like receptor 9-mediated inflammation and the activation of NRLP3-inflammasome [80, 81]. In a study conducted by Collins et al. [82], they found that the injection of mtDNA into mice synovial fluid resulted in severe inflammation and arthritis. However, the specific mechanisms regulating the immune system activity after mtDNA entrance to the cytosol remain unclear. Therefore, developing techniques for the intact and safe transfer of functional mitochondria to the target cells may accelerate exogenous mitochondrial donation for therapeutic purposes.

\section{Mitochondrial transfer in vivo condition}

Although the phenomenon of mitochondrial transfer in cell culture conditions has been widely described, it is necessary to confirm whether the mitochondrial transfer can occur in in-vivo conditions. Recently, experimental data indicated that injured neurons can capture functional mitochondria from astrocytes [83]. In this regard, $\mathrm{CD} 38 / \mathrm{CADPR} / \mathrm{Ca}^{2+}$ signaling may help astrocytes transfer mitochondria into neurons to promote survival and plasticity. Besides, Hayakawa et al. [6] collected extracellular mitochondria particles from primary mouse cortical astrocytes and then directly injected them into the peri-infarct cortex of mouse models of focal cerebral ischemia. After $24 \mathrm{~h}$, it was found that the transplanted functional mitochondria were indeed present in neurons and cell survival signals were amplified. It seems that this process takes place during life as a dynamic process. For example, Yi et al. [84] observed mitochondrial transfer happens during embryonic development. They collected mitochondria concentrates from murine hepatocytes and then injected them into zygotes from older mice. They showed better developmental outcomes in the injected group, indicating that mitochondrial transfer can improve embryonic development. The replacement of mitochondria through nuclear transfer among oocytes has recently come into a research focus as a strategy for preventing the inheritance of mtDNA diseases [85].

Stem cells are recognized as unexceptionable donor cells for mitochondrial transfer [41]. The first evidence for mitochondrial transfer as an in-vivo therapeutic tool came from Islam et al's study [53]. In the sepsis acute lung injury model (airway-instilled E. coli LPS in anesthetized mice), BMSCs successfully transferred mitochondrial 
cargo to the alveolar epithelium followed by an increased ATP content and enhanced alveolar surfactant production. In such non-sterile inflammatory disease, the activation of alveolar macrophages with lipopolysaccharide makes these cells to accept mitochondria from stem cells to reduce the production of inflammatory factors. At the same time, ATP production and cell phagocytic function are stimulated $[53,86]$. Lung alveolar macrophages have been shown to gain mitochondria from MSCs in both in vitro and in vivo models of acute respiratory distress syndrome resulting in the promotion of macrophage phagocytosis and improvement of bioenergetics [87]. Guo et al. [88] found that the formation of TNTs after viral infections via porcine reproductive and respiratory syndrome virus. It seems that this strategy could be effective in the transfer of stem cells-derived mitochondria to infected cells, prohibiting infected cells from apoptosis/ necrosis. In sterile inflammatory diseases, stem cells are capable of alleviating the inflammatory response and rescuing injured cells [89-91]. For instance, Naji et al. indicated that the NLRP3-ASC-Caspase 1 axis induced via indium-tin-oxide nanoparticles in macrophages can provoke pyroptosis, while stem cells can inhibit the inflammatory process and rescue cardiomyoblasts from ischemia via direct cell-to-cell connections $[92,93]$. Li et al. discovered that the donation of mitochondria from MSCs provides great promise for the recovery of cigarette smoke-induced lung injury in chronic obstructive pulmonary disease [40]. Notably, it is reported that there is a higher mitochondrial transfer capacity in iPSC-MSCs than that from BMSCs to repair CS-induced mitochondrial damage [94].

Mitochondria from injured somatic cells could be engulfed and degraded by stem cells which results in the induction of the cytoprotective enzyme heme oxygenase-1, an improvement of cellular proliferation and anti-apoptotic function $[95,96]$. Thus, intercellular mitochondrial transfer using stem cells as a carrier holds a new approach to cure mitochondrial dysfunctional diseases [97].

\section{Molecular mechanism of mitochondrial transferring between cells}

Organelle exchange between cells can occur via three potential means: TNTs, EVs, and cellular fusion.

\section{TNT-dependent mitochondria internalization mechanism}

TNTs are small membranous tubes, with $50-1000 \mathrm{~nm}$ in diameter, seen in stem cells during mitochondrial transfer. TNTs are thin cytoplasmic extensions bordered by a plasma membrane to create a connection bridge between cells. TNTs were initially described by Rustom et al. [42] as a communicating intercellular transport network formed in the co-culture of human 293 cells and rat PC12 cells. Later, TNT formation was also reported in immune cells, including $\mathrm{B}, \mathrm{T}$, and NK cells, neutrophils, and monocytes, as well as in neurons, glial cells, prostate cancer cells, and cardiomyocytes. It is thought that TNTs are key points for effective mitochondrial transfer [57, 98]. Onfelt et al. observed that thin filaments involving F-actin and also a thicker subset $(0.7 \mu \mathrm{m})$ containing both F-actin and microtubules participated in the formation of TNTs [99]. Meanwhile, M-sec, a mammalian protein, can induce the formation of TNTs that only contain actin filaments, but without microtubules [100]. Also, the exchange of cell particles between injured cells and stem cells was required for the formation of TNTs [47]. Also, Cdc42 (a small GTPase) plays a critical role in the TNT extension process [100]. Furthermore, the mitochondrial transfer can be induced via mitochondrial damage that releases ROS to activate NF- $\mathrm{kB}$ and upregulate TNFoip2, thereby enhancing the formation of TNTs [101]. Besides, the formation of TNTs was demonstrated to be controlled by some external factors. It was observed that high concentrations of glucose play two-sided roles in the formation of TNTs. High concentrations of glucose were shown to diminish mitochondrial motility and inhibit mitochondrial trafficking in neurons via regulating Milton and its O-GlcNAcylation [102]. Moreover, TNT-mediated mitochondrial transfer from MSCs to endothelial cells was enhanced by glucose deprivation [47]. Other conditions such as low serum contents, acidic $\mathrm{pH}$, exposure to $\mathrm{H}_{2} \mathrm{O}_{2}$, viral infection, or treatment with chemotherapeutic agents promote the formation of TNTs [50, 58, 59, 103-105]. Overall, the microenvironment around injured cells might be suited to the formation of TNTs, which is beneficial to the mitochondrial transfer. Therefore, these conditions must be defined concerning cell type and milieu. MSCs could transfer mitochondria to damaged acceptor cells via actin-based intercellular structures [106]. These cells actively transferred mitochondrial mass to NSCs and act as a shield to protect NSCs against the neurotoxic effects of cisplatin [106]. On the other hand, MSCs-to-NSCs mitochondrial transfer reversed the cisplatin-induced reduction of mitochondrial membrane potential. The inhibition of actin-based cytoskeletal re-arrangement inhibited the transfer of mitochondria to NSCs and abrogated the positive effects of MSCs on NSC survival. Conversely, overexpression of the Miro1 in MSCs increased mitochondrial transfer and further improved survival of cisplatin-treated NSCs. The activity of accessory proteins like TRAK 1 and TRAK 2 [107, 108], Myo 19, and Myo 10 [109] permit the efficient shipping of cargo between 
cells guided by actin-myosin-dependent mechanisms (FIG. 2a) [110]. Other experiments revealed that in vivo MSC administration prevented the loss of $\mathrm{DCX}^{+} \mathrm{NSCs}$ in the subventricular zone and hippocampal dentate gyrus in animals treated with cisplatin [106]. It was shown that MSCs could donate mitochondria and protect corneal cells against oxidative stress-induced mitochondrial dysfunction. In a co-culture of MSCs and CECs, the mitochondrial transfer was enhanced from MSCs to CECs after treatment with Rotenone (Rot)induced oxidative stress [101]. Separation of MSCs and CECs by a Transwell ${ }^{\circledR}$ culture system aborted mitochondrial transfer from MSCs to CECs. Mechanistically, increased filopodia outgrowth in CECs for TNT formation was associated with oxidative inflammationactivated NF- $\kappa \mathrm{B} / \mathrm{TNF} \alpha \mathrm{ip} 2$ signaling pathways that could be attenuated by reactive oxygen species scavenger $N$-acetyl cysteine treatment. Furthermore, MSCs grown on a decellularized porcine corneal scaffold were transplanted onto an alkali-injured eye in a rabbit model [101]. Enhanced corneal wound healing was evident following healthy MSC scaffold transplantation and transferred mitochondria were detected in corneal epithelium. Mitochondrial transfer from MSCs provides novel protection for the cornea against oxidative stress-induced mitochondrial damage [101]. The balance between mitochondrial fusion and fission events pre-determines the morphological adaption of this organelle in target cells. Even, the precise and successful cross-talk between de novo mitochondrial source with host cell mitochondrial pool and other organelles ensues efficient proteomic and genomic modulation and participation of mtDNA in favor of cell bioactivities $[111,112]$. However, it is a naïve idea to imagine that mitochondria transfer is commonly accepted by the target cells and in most cases, the cell-based mitochondrial activity could not be restored even after mitochondrial transport [46].

\section{Cell fusion}

Cell fusion is another mechanism by which cells are interconnected physically by the plasma membrane of two distinct cell types with retained nuclear morphology. Under these situations, cytosolic constituents and organelles are evenly shared between juxtaposed cells with a permanent fusion. Although, partial cell fusion could also exchange subcellular organelles, like mitochondria, and protein complexes, this kind of fusion is rare and happens under specific circumstances [113]. Similar to vesicular fusion and secretion, the mitochondrial transfer is started since the mitochondria outer membrane has physical contact with the plasma membrane. Similar to the formation of TNTs for mitochondrial distribution, the majority of molecular pathways are the same as the above-mentioned (Fig. 3) [114].

\section{Role of extracellular vesicles in directing the intercellular mitochondrial transfer}

Organelle transfer is actively seen between cells via the secretion of micro and nano-sized EVs. EVs are found in numerous in vivo samples such as urine, plasma, etc. Based on the size and route of biogenesis, EVs are classified into three main categories: exosomes, microvesicles, and apoptotic bodies [63, 115]. Exosomes are small homogenous membrane-coated vesicles ranging from 30 to $100 \mathrm{~nm}$ in diameter $[116,117]$. Upon reaching the target cells, EVs are internalized and release their cargo to acceptor cells. Therefore, EVs act as messengers for longand short-distance crosstalk among the cells [118-120]. Due to their small size, it is unlikely that microvesicles and nano-vesicles such as exosomes (ranging from 40 to $200 \mathrm{~nm}$ ) carry mitochondria, but these elements are touted as suitable bio-shuttles to transfer the factors that facilitate the mitochondrial transfer between the cells (Fig. 3). Increasing evidence showed that exosomes are eligible mediators for harboring mitochondrial genome to the recipient cells [121]. Most notably, mtDNA-laden exosomes could be considered as an alternative method to transfer mitochondrial associated bioactivity to specific cells in addition to direct mitochondrial transfer. The ability of exosomes and EVs to transfer other genetic elements that are potent to regulate mitochondrial activity inspires the fact that these vesicles could indirectly affect the mitochondrial related activity in the candidate cells. Since the interaction of exosomes with the target cells is governed by different exosome-cell interactions, it is mighty to imagine that the induction of protective effects via mitochondrial genome hindered by exosomes in a paracrine changing the metabolism of multiple cells at the same time. In this regard, Islam et al. reported the term EV-mediated mitochondrial transfer in MSCs towards alveolar epithelial cells [122]. Other experiments done by Phinney et al. confirmed that MSC EVs could transfer functional mitochondria that were successfully internalized by macrophages contributed to activated oxidative phosphorylation. Irrespective of the fact that mitochondria could shed protective effects by exosomes cargo or EVs indirectly regulates mitochondrial activity in the target cells by other elements, both implications contribute to inspiration of definite implication that exosomes and/or EVs are active or passive modulators of mitochondrial activity in the target cells. Due to size limitation, it is an illusion to conceive that exosomes could carry mitochondrial mass between cells while large-sized EVs such as apoptotic bodies (ranging 


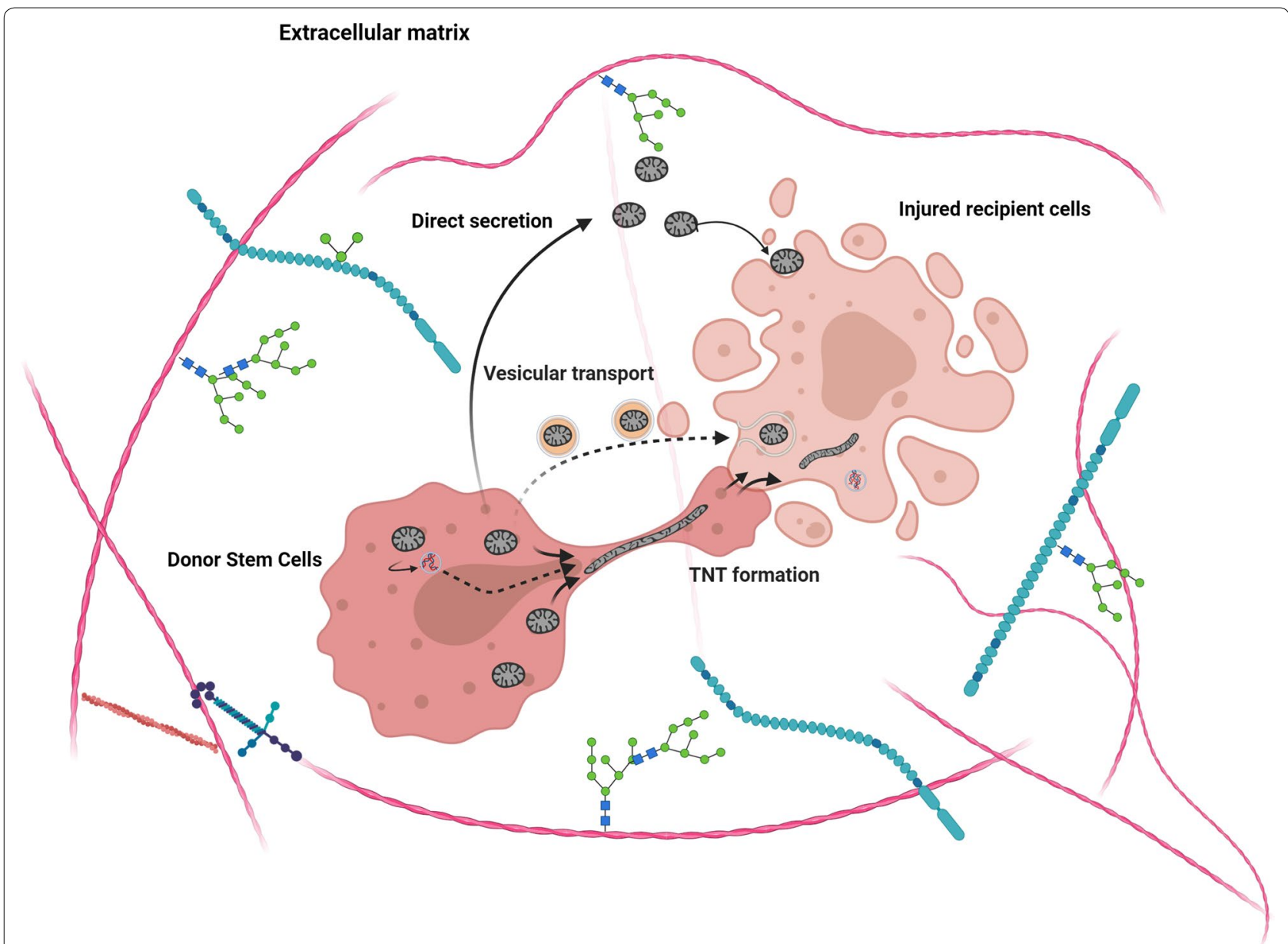

Fig. 3 Different pathways are available for mitochondrial transfer between the cells. The common method for mitochondria transfer is done via TNT bridges while mitochondrial fragments or products, mtDNA, could be transferred via extracellular vesicles. In some cases, the mitochondrial mass is directly engulfed by the acceptor cells

from 500 to $1,000 \mathrm{~nm}$ ) are mighty eligible to carry mitochondria which have comparable sizes [123]. In support of this claim, cells undergoing apoptotic changes could be touted as a mitochondrial exporter to juxtaposed or remote cells. As above-mentioned in this article, cells with injuries are at the center of attention and the proinflammatory condition makes these cells to affect the activity of mitochondria in other cells. In conclusion, due to the dynamic state of cells under pathological and physiological conditions, it is not unlikely to say that each cell could be introduced as mitochondrial exporter and/ or receiver depended on the milieu and energy demands.

\section{Mitochondrial transfer in the field of cardiovascular disease}

It has been well-documented that MSCs could release an array of soluble factors like growth factors, cytokines, and chemokines [124]. According to mechanisms of action, different reparative aspects are affected soon after the transplantation of MSCs into injured cardiac tissue. These cells could increase capillary density (angiogenesis), and regulate cardiac contractility, fibrosis, and remodeling [1, 125]. Besides, the number of apoptotic cardiomyocytes is reduced via the secretion of factors such as VEGF, FGF-2, HGF, IGF-I, leading to enhanced cardiac function [126]. The secretion of specific cytokines, $\mathrm{PGE}_{2}$, IL-10, etc. could help the local cardiomyocytes to protect themselves from subsequent inflammatory response cascades [124, 127]. Commensurate with these comments, a plethora of documents have shown that paracrine activity and regulation of inflammatory responses are the main underlying mechanisms driven by MSCs rather than in situ proliferation and differentiation toward cardiomyocyte-like cells [128]. Regarding the high intracellular mitochondrial content in the cardiovascular system, it is logical to mention that the transfer of mitochondria to vascular and cardiac cell lineages reveals potentially therapeutic effects. The transfer of mitochondria from MSCs or other stem cell 
Table 1 Transfer of mitochondrial donation in different in vivo and in vitro systems

\begin{tabular}{|c|c|c|c|c|}
\hline Milieu & Donor cells & Recipient cells & Outcome & References \\
\hline \multirow[t]{2}{*}{ In vitro } & \multirow[t]{2}{*}{ Human bone marrow MSCs } & \multirow[t]{2}{*}{ Adult mouse cardiomyocytes } & $\begin{array}{l}\text { Mitochondrial transfer is required for } \\
\text { somatic cell reprogramming }\end{array}$ & \multirow[t]{2}{*}{ [129] } \\
\hline & & & $\begin{array}{l}\text { Heterologous cell fusion promoted } \\
\text { cardiomyocyte reprogramming back } \\
\text { to a progenitor-like state. }\end{array}$ & \\
\hline \multirow[t]{3}{*}{ In vivo } & \multirow[t]{3}{*}{$\begin{array}{l}\text { Human induced-pluripotent-stem-cell- } \\
\text { derived MSCs (iPSC-MSCs) }\end{array}$} & \multirow[t]{3}{*}{ Cardiomyocytes } & $\begin{array}{l}\text { iPSC-MSCs has superior effect to transfer } \\
\text { mitochondria due to enhanced } \\
\text { expression of Miro-1 }\end{array}$ & \multirow[t]{3}{*}[72]{} \\
\hline & & & $\begin{array}{l}\text { The higher levels of TNFaIP2 expression } \\
\text { in iPSC-MSCs make them respond } \\
\text { to TNF-a-induced TNT formation to } \\
\text { transfer mitochondria to anthracy- } \\
\text { cline-induced cardiomyocytes. }\end{array}$ & \\
\hline & & & $\begin{array}{l}\text { Suppression of TNFalP2 or MIRO1 in } \\
\text { iPSC-MSCs aborted mitochondrial } \\
\text { transfer. }\end{array}$ & \\
\hline In vitro & Human MSCs & Rat cardiomyocytes & $\begin{array}{l}\text { The co-culture of rat cardiomyocytes } \\
\text { with human MSCs increased the } \\
\text { number of TNTs. }\end{array}$ & {$[142]$} \\
\hline \multirow[t]{2}{*}{ In vitro and in vivo } & \multirow[t]{2}{*}{$\begin{array}{l}\text { Rabbit fibroblast isolated from cardiac } \\
\text { tissue }\end{array}$} & \multirow[t]{2}{*}{ Adult rabbits cardiomyocytes } & $\begin{array}{l}\text { An inter-cytoplasmic connection is } \\
\text { provided between fibroblasts and } \\
\text { dedifferentiated cardiomyocytes. }\end{array}$ & \multirow[t]{2}{*}[143]{} \\
\hline & & & $\begin{array}{l}\text { Disruption of the basal lamina was initi- } \\
\text { ated after TNT formation in the border } \\
\text { zone of a rabbit myocardial infarction. }\end{array}$ & \\
\hline \multirow[t]{2}{*}{ In vitro } & \multirow[t]{2}{*}{ Normal mouse MSCs } & \multirow[t]{2}{*}{ Ischemic H9C2 cardiomyoblasts } & $\begin{array}{l}\text { Wide }(200-500 \mathrm{~nm}) \text { intercellular con- } \\
\text { nections formed between the rat } \\
\text { cardiomyoblasts and mouse MSCs }\end{array}$ & \multirow[t]{2}{*}[93]{} \\
\hline & & & $\begin{array}{l}\text { Cell fusion rarely occurred between the } \\
\text { rat cardiomyoblasts and mouse MSCs. }\end{array}$ & \\
\hline \multirow[t]{3}{*}{ In vitro } & \multirow[t]{3}{*}{ Rat MSCs } & \multirow[t]{3}{*}{ Rat neonatal cardiomyocytes } & $\begin{array}{l}\text { MSCs make cell-to-cell connection by } \\
\text { initial extension of filopodia. }\end{array}$ & \multirow[t]{3}{*}{ [134] } \\
\hline & & & $\begin{array}{l}\text { Unidirectional transfer of mitochondria } \\
\text { occurred between MSCs and cardio- } \\
\text { myocytes. }\end{array}$ & \\
\hline & & & $\begin{array}{l}\text { Compared to the MSCs, few TNT forma- } \\
\text { tions were observed between the car- } \\
\text { diac fibroblasts and cardiomyocytes in } \\
\text { a homotypic or mixed cell population. }\end{array}$ & \\
\hline In vivo & Mouse astrocytes & Mouse neurons & $\begin{array}{l}\text { CD38 and cyclic ADP ribose signaling } \\
\text { participate in mitochondrial transfer }\end{array}$ & {$[6]$} \\
\hline \multirow[t]{3}{*}{ In vitro } & \multirow[t]{3}{*}{ Bone marrow MSCs } & \multirow[t]{3}{*}{ Rat renal tubular cells } & $\begin{array}{l}\text { The transport of cellular components } \\
\text { was started three hours after co- } \\
\text { culturing }\end{array}$ & \multirow[t]{3}{*}[144]{} \\
\hline & & & $\begin{array}{l}\text { Both anterograde and retrograde mito- } \\
\text { chondrial transfer were seen between } \\
\text { the MSCs and renal tubular cells. }\end{array}$ & \\
\hline & & & $\begin{array}{l}\text { Renal-specific Tamm-Horsfall protein } \\
\text { was induced in MSCs after connection } \\
\text { to the renal cells, promoting MSCs dif- } \\
\text { ferentiation toward tubular cells. }\end{array}$ & \\
\hline
\end{tabular}


Table 1 (continued)

\begin{tabular}{|c|c|c|c|c|}
\hline Milieu & Donor cells & Recipient cells & Outcome & References \\
\hline In vitro & $\begin{array}{l}\text { Adult human endothelial progenitor } \\
\text { cells }\end{array}$ & Rat cardiomyocytes & $\begin{array}{l}\text { The number endothelial progenitor cell- } \\
\text { derived TNTs increased six hours after } \\
\text { co-culturing. } \\
\text { Transport of MitoTracker-positive struc- } \\
\text { tures was done from cardiomyocyte } \\
\text { toward endothelial progenitor cells. } \\
\text { The acquisition of a cardiomyogenic } \\
\text { phenotype was recorded in endothe- } \\
\text { lial progenitor cells independent of } \\
\text { cellular or nuclear fusion. }\end{array}$ & [133] \\
\hline In vitro & Human bone marrow MSCs & $\begin{array}{l}\text { Human umbilical vein endothe- } \\
\text { lial cells (HUVECs) }\end{array}$ & $\begin{array}{l}\text { TNT-like structure was performed } \\
\text { between MSCs and HUVECs. } \\
\text { Oxygen/glucose deprivation and } \\
\text { re-oxygenation in HUVECs induced } \\
\text { unidirectional mitochondrial transfer } \\
\text { through TNTs from MSCs. } \\
\text { Formation of TNTs is a defense and } \\
\text { rescue mechanism after exposure of } \\
\text { phosphatidylserine on the surface of } \\
\text { apoptotic endothelial cells. }\end{array}$ & {$[47]$} \\
\hline In vitro and in vivo & Neonatal rat cardiomyocytes & Neonatal rat cardiomyocytes & $\begin{array}{l}\text { Mitochondrial internalization is done } \\
\text { through actin-dependent endocy- } \\
\text { tosis. } \\
\text { Internalized mitochondria replenished } \\
\text { cardiomyocyte ATP content. } \\
\text { Oxygen consumption increased after } \\
\text { mitochondrial internalization. }\end{array}$ & {$[136]$} \\
\hline In vitro and in vivo & Cardiac fibroblasts & Myocytes & $\begin{array}{l}\text { In response to cardiac injury, interac- } \\
\text { tions between myofibroblasts and } \\
\text { myocytes are enhanced, contributing } \\
\text { to significant electrophysiological } \\
\text { changes and influencing electrotonic } \\
\text { connectivity between cardiomyocytes } \\
\text { and fibroblasts and/or myofibroblasts }\end{array}$ & {$[145]$} \\
\hline In vitro & Human uterine endometrial gland MSCs & Rat H9C2 cardiomyoblasts & $\begin{array}{l}\text { Mitochondrial transfer was seen in } \\
\text { homogeneic and xenogeneic cells. } \\
\text { Mitochondrial transfer rescued the } \\
\text { mitochondrial respiratory function } \\
\text { and improved the cellular viability in } \\
\text { mitochondrial DNA-depleted cells. } \\
\text { Micropinocytosis participates in mito- } \\
\text { chondrial internalization. }\end{array}$ & {$[140]$} \\
\hline In vitro & Rat MSCs & Neonatal cardiomyocytes & $\begin{array}{l}\text { Connexin- } 43 \text { was induced as junctional } \\
\text { factors between the MSCs and cardio- } \\
\text { myocytes. } \\
\text { MSC-cardiomyocyte fusion was initiated. } \\
\text { Partial cell fusion and TNT accelerated } \\
\text { the transfer of MSC mitochondria to } \\
\text { the cardiomyocytes. }\end{array}$ & {$[146]$} \\
\hline
\end{tabular}


Table 1 (continued)

\begin{tabular}{|c|c|c|c|c|}
\hline Milieu & Donor cells & Recipient cells & Outcome & References \\
\hline \multirow[t]{3}{*}{ In vitro and in vivo } & Rat cardiac fibroblasts & Neonatal rat cardiomyocytes & $\begin{array}{l}\text { Microtubules and motor protein KIF5B } \\
\text { are required for mitochondrial trans- } \\
\text { port from fibroblasts to cardiomyo- } \\
\text { cytes. }\end{array}$ & [147] \\
\hline & & & $\begin{array}{l}\text { The mitochondrial transfer was } \\
\text { observed from fibroblast to hypoxia- } \\
\text { treated cardiomyocytes but not vice } \\
\text { versa }\end{array}$ & \\
\hline & & & $\begin{array}{l}\text { Intact and hypoxia/re-oxygenation- } \\
\text { treated fibroblast decreased cardio- } \\
\text { myocyte apoptosis by mitochondrial } \\
\text { donation via TNTs. }\end{array}$ & \\
\hline \multirow[t]{4}{*}{ In vitro and in vivo } & $\begin{array}{l}\text { Human-induced pluripotent stem cell } \\
\text { (iPSC)-derived MSCs }\end{array}$ & Asthmatic epithelial cells & $\begin{array}{l}\text { iPSC-MSC transplantation decreased } \\
\text { Thelper } 2 \text { related cytokines and } \\
\text { blunted mitochondrial dysfunction in } \\
\text { epithelial cells }\end{array}$ & [148] \\
\hline & & & $\begin{array}{l}\text { TNTs were formed between iPSC-MSCs } \\
\text { and epithelial cells }\end{array}$ & \\
\hline & & & $\begin{array}{l}\text { Mitochondrial transfer was done from } \\
\text { iPSC-MSCs to epithelial cells via TNTS }\end{array}$ & \\
\hline & & & $\begin{array}{l}\text { Connexin } 43 \text { plays a critical role in the } \\
\text { regulation of TNT formation in iPSC- } \\
\text { MSCs. }\end{array}$ & \\
\hline
\end{tabular}

types to cardiomyocytes and different adult cells was confirmed previously $[6,129]$ (Table 1 ). It is worth mentioning that the accumulation of pro-inflammatory cytokines such as TNF- $\alpha$, IL- 6 , etc. at the site of injury could induce massive cytoskeletal re-arrangement in transplant stem cells, leading to facilitation in the formation of TNTs and mitochondrial transfer to neighbor cells. Recently, inflammation-associated mitochondrial donation of MSCs to different cell lineages such as cancer cells, retinal cells, and pulmonary epithelial cells has been proved [130]. These features show that the regenerative effects of stem cells and the extent and direction of mitochondrial transfer highly depend on a microenvironment. Calling attention, a pro-inflammatory environment is an incentive factor to maintain MSC-derived mitochondrial transfer immune cells such as $\mathrm{T}$ lymphocytes which per se regulate host immune cells activity [131]. Along with these comments, it seems that there is a close association between MSCs paracrine activity and mitochondrial donation to promote regeneration of cardiac tissue. Of course, it should be noted that the severity of inflammatory responses should not be such that disrupt the potential ability of MSCs to transfer mitochondria to acceptor cells. Considering the promising cardioprotective outcomes after mitochondria transplantation in different animal models, the establishment of the first clinical trial in pediatrics myocardial ischemia-reperfusion injury paved a way to cure patients with cardiac insufficiencies [132]. Although the ability of source cells, such as MSCs, have been confirmed in the formation of TNTs for mitochondrial distribution, it seems that the use of appropriate cells could yield therapeutic outcomes [133]. In contrast to fibroblasts with limited mitochondrial supply, ex vivo modulation of MSCs potentiates these cells to form TNTs for better mitochondrial transfer [134]. The direct or indirect injection of exogenous mitochondria showed a fast-cellular internalization of these organelles by various cardiac resident cells such as cardiomyocytes and fibroblasts by the restoration of mtDNA and energy demands $[135,136]$. The cross-talk between cardiac and non-cardiac cells pre-determines the efficiency of mitochondrial therapy $[137,138]$. The route of mitochondrial introduction is considered as a critical step in the restoration of the cardiac outcome. Intracoronary infusion of mitochondria yielded in the fast and efficient distribution of mitochondria throughout the whole cardiac tissue. This strategy enables us to use a high therapeutic dose of mitochondrial therapy as was previously used in Langendorff-perfused rabbit infarcted cardiac tissue [135]. The engagement of Caveolae-dependent-clathrin dependent endocytosis, actin-meditated endocytosis, TNTs formation, actin-mediated endocytosis, and macro-pinocytosis is thought to be underlying mechanisms in mitochondrial therapy of cardiac insufficiencies $[59,139,140]$. The lack of mitochondrion-lysosome fusion in target cardiomyocytes revealed the exploitation of anti-phagocytic mechanisms to exclude newly entered mitochondria [141]. 


\section{Conclusion}

It seems that mitochondrial transfer could be touted as a novel and efficient approach in which stem cells could exert therapeutic outcomes in the injured tissues. Due to the complexity of the mechanisms involved in mitochondrial donation, the impact of different factors such as the impact of type and intensity damage in the ability of cells to obtain mitochondria, the potential capacity of mitochondrial donor cells, alternative routes participating in mitochondrial transfer should be addressed in the future studies.

\begin{abstract}
Abbreviations
BMSCs: Bone marrow mesenchymal stem cells; CECs: Corneal epithelial cells; EVs: Extracellular vesicles; FGF: Fibroblast growth factor; HGF: Hepatocyte growth factor; IGF-I: Insulin-like growth factor-l; IL-10: Interleukin 10; Miro1: Mitochondrial motor protein Rho-GTPase 1; NSCs: Neural stem cells; PGE2: Prostaglandin E2; TNFa: Tumor necrosis factor-a; TNTs: Tunneling nanotubes; VEGF: Vascular endothelial growth factor.
\end{abstract}

\section{Acknowledgment}

Authors thanks the personnel of Stem Cell Research for help and guidance

\section{Authors' contributions}

$\mathrm{HSB}$ and $A Z$, and FB collected data and prepared the manuscript. RRES and ST contributed to the manuscript. RR and ES supervised the study. All authors read and approved the final manuscript.

\section{Funding}

This study was funded by a grant (IR.TBZMED.VCR.REC.1398.296) from Tabriz University of Medical Sciences.

\section{Availability of data and materials}

Not applicable.

Ethics approval and consent to participate

Not applicable.

\section{Consent for publication}

Not applicable.

\section{Competing interests}

The authors declare that they have no competing interests.

\section{Author details}

${ }^{1}$ School of Medicine, Biophysics Department, Koç University, Rumeli Fener, Sarıyer, Istanbul, Turkey. ${ }^{2}$ Department of Medical Nanotechnology, Faculty of Advanced Medical Sciences, Tabriz University of Medical Sciences, Tabriz, Iran. ${ }^{3}$ Koç University Translational Medicine Research Center (KUTTAM) Rumeli Feneri, Sarıyer, Istanbul, Turkey. ${ }^{4}$ Faculty of Engineering, Mechanical Engineering Department, Koç University, Rumeli Feneri Yolu, Sarıer, Istanbul, Turkey. ${ }^{5}$ Stem Cell Research Center, Tabriz University of Medical Sciences, Tabriz, Iran. ${ }^{6}$ Department of Applied Cell Sciences, Faculty of Advanced Medical Sciences, Tabriz University of Medical Sciences, Imam Reza St., Daneshgah St. 51666-14756 Tabriz, Iran.

Received: 17 June 2020 Accepted: 15 September 2020 Published online: 25 September 2020

\section{References}

1. Rahbarghazi R, Nassiri SM, Ahmadi SH, Mohammadi E, Rabbani S, Araghi A, Hosseinkhani H. Dynamic induction of pro-angiogenic milieu after transplantation of marrow-derived mesenchymal stem cells in experimental myocardial infarction. Int J Cardiol. 2014;173(3):453-66.
2. Trounson A, Thakar RG, Lomax G, Gibbons D. Clinical trials for stem cell therapies. BMC Med. 2011;9:52-52. https://doi. org/10.1186/1741-7015-9-52.

3. Lee MW, Yang MS, Park JS, Kim HC, Kim YJ, Choi J. Isolation of mesenchymal stem cells from cryopreserved human umbilical cord blood. Int J Hematol. 2005;81(2):126-30.

4. Lukomska B, Stanaszek L, Zuba-Surma E, Legosz P, Sarzynska S, Drela K. Challenges and controversies in human mesenchymal stem cell therapy. Stem Cells Int. 2019;2019:9628536.

5. Rahbarghazi R, Nassiri SM, Khazraiinia P, Kajbafzadeh AM, Ahmadi SH, Mohammadi E, Molazem M, Zamani-Ahmadmahmudi M. Juxtacrine and paracrine interactions of rat marrow-derived mesenchymal stem cells, muscle-derived satellite cells, and neonatal cardiomyocytes with endothelial cells in angiogenesis dynamics. Stem Cells Dev. 2013;22(6):855-65. https://doi.org/10.1089/scd.2012.0377.

6. Hayakawa K, Esposito E, Wang X, Terasaki Y, Liu Y, Xing C, Ji X, Lo EH. Transfer of mitochondria from astrocytes to neurons after stroke. Nature. 2016;535(7613):551-5. https://doi.org/10.1038/nature18928.

7. Tzameli I. The evolving role of mitochondria in metabolism. Trends Endrocrinol Metab. 2012;23(9):417-9.

8. Liu K, Lin L, Li Q, Xue Y, Zheng F, Wang G, Zheng C, Du L, Hu M, Huang Y. Scd1 controls de novo beige fat biogenesis through succinatedependent regulation of mitochondrial complex II. Proc Natl Acad Sci USA. 2020;117(5):2462-72

9. Ji LL, Yeo D, Kang C, Zhang T. The role of mitochondria in redox signaling of muscle homeostasis. J Sport Health Sci. 2020;9(5):386-93.

10. Gentiluomo M, Katzke VA, Kaaks R, Tjonneland A, Severi G, Perduca V, Boutron-Ruault M-C, Weiderpass E, Ferrari P, Johnson T. Mitochondrial DNA copy number variation and pancreatic cancer risk in the prospective EPIC cohort. Cancer Epidemiol Biomarkers Prev. 2020;29(3):681-6.

11. Cole LW. The evolution of per-cell organelle number. Front Cell Dev Biol. 2016:4:85.

12. Kühlbrandt W. Structure and function of mitochondrial membrane protein complexes. BMC Biol. 2015;13(1):89.

13. Ten VS, Ratner V. Mitochondrial bioenergetics and pulmonary dysfunction: current progress and future directions. Paediatr Respir Rev. 2019;34:37-45.

14. Fernie AR, Carrari F, Sweetlove LJ. Respiratory metabolism: glycolysis, the TCA cycle and mitochondrial electron transport. Curr Opin Plant Biol. 2004;7(3):254-61.

15. Mitchell P. Coupling of phosphorylation to electron and hydrogen transfer by a chemi-osmotic type of mechanism. Nature. 1961;191(4784):144-8.

16. Reichert AS, Neupert WT. Mitochondriomics or what makes us breathe. Trends Genet. 2004;20(11):555-62.

17. Neupert W, Herrmann JM. Translocation of proteins into mitochondria. Annu Rev Biochem. 2007;76:723-49.

18. Norberg E, Orrenius S, Zhivotovsky B. Mitochondrial regulation of cell death: processing of apoptosis-inducing factor (AIF). Biochem Biophys Res Commun. 2010;396(1):95-100.

19. Ott M, Gogvadze V, Orrenius S, Zhivotovsky B. Mitochondria, oxidative stress and cell death. Apoptosis. 2007;12(5):913-22.

20. Venditti P, Di Stefano L, Di Meo SJM. Mitochondrial metabolism of reactive oxygen species. Mitochondrion. 2013;13(2):71-82.

21. Owen OE, Kalhan SC, Hanson RW. The key role of anaplerosis and cataplerosis for citric acid cycle function. J Biol Chem. 2002;277(34):30409-122.

22. Cheng Z, Ristow M. Mitochondria and metabolic homeostasis. Antioxid Redox Signal. 2013;19(3):240-2.

23. Nunnari J, Suomalainen A. Mitochondria: in sickness and in health. Cell. 2012;148(6):1145-59.

24. Kryven I, Röblitz S, Schütte C. Solution of the chemical master equation by radial basis functions approximation with interface tracking. BMC Syst Biol. 2015;9(1):67

25. Gu W, Gaeta X, Sahakyan A, Chan AB, Hong CS, Kim R, Braas D, Plath K, Lowry WE, Christofk HR. Glycolytic metabolism plays a functional role in regulating human pluripotent stem cell state. Cell Stem Cell. 2016;19(4):476-90.

26. Tang J, Peng R, Ding J. The regulation of stem cell differentiation by cell-cell contact on micropatterned material surfaces. Biomaterials. 2010;31(9):2470-6. 
27. Curran JM, Chen R, Hunt JA. The guidance of human mesenchymal stem cell differentiation in vitro by controlled modifications to the cell substrate. Biomaterials. 2006;27(27):4783-93.

28. Lonergan T, Brenner C, Bavister BJ. Differentiation-related changes in mitochondrial properties as indicators of stem cell competence. J Cell Physiol. 2006;208(1):149-53.

29. Hoffmann $\mathrm{C}$, Höckele $\mathrm{S}$, Kappler $\mathrm{L}$, de Angelis $\mathrm{MH}$, Häring $\mathrm{H}-\mathrm{U}$, Weigert $C$. The effect of differentiation and TGF $\beta$ on mitochondrial respiration and mitochondrial enzyme abundance in cultured primary human skeletal muscle cells. Sci Rep. 2018;8(1):737.

30. Barnett DK, Kimura J, Bavister BD. Translocation of active mitochondria during hamster preimplantation embryo development studied by confocal laser scanning microscopy. Dev Dyn. 1996;205(1):64-72.

31. Rhee SG, Kang SW, Chang TS, Jeong W, Kim K. Peroxiredoxin, a novel family of peroxidases. IUBMB Life. 2001;52(1):35-41.

32. Cho YM, Kwon S, Pak YK, Seol HW, Choi YM, Park DJ, Park KS, Lee HK. Dynamic changes in mitochondrial biogenesis and antioxidant enzymes during the spontaneous differentiation of human embryonic stem cells. Biochem Biophys Res Commun. 2006;348(4):1472-8.

33. Sauer $H$, Wartenberg $M$, Hescheler J. Reactive oxygen species as intracellular messengers during cell growth and differentiation. Cell Physiol Biochem. 2001;11(4):173-86.

34. Sauer $\mathrm{H}$, Wartenberg $M$. Reactive oxygen species as signaling molecules in cardiovascular differentiation of embryonic stem cells and tumorinduced angiogenesis. Antioxid Redox Signal. 2005;7(11-12):1423-34.

35. Chung S, Dzeja PP, Faustino RS, Perez-Terzic C, Behfar A, Terzic A. Mitochondrial oxidative metabolism is required for the cardiac differentiation of stem cells. Nat Clin Pract Cardiovasc Med. 2007;4(S1):S60.

36. Plotnikov EY, Marei M, Podgornyi O, Aleksandrova M, Zorov D, Sukhikh G. Functional activity of mitochondria in cultured neural precursor cells. Bull Exp Biol Med. 2006;141(1):142-6.

37. Zhang F, Jiang L, He Y, Fan W, Guan X, Deng Q, Huang F, He H. Changes of mitochondrial respiratory function during odontogenic differentiation of rat dental papilla cells. J Mol Histol. 2018;49(1):51-61.

38. Pouyafar A, Heydarabad MZ, Abdolalizadeh J, Rahbarghazi R, Talebi M. Modulation of lipolysis and glycolysis pathways in cancer stem cells changed multipotentiality and differentiation capacity toward endothelial lineage. Cell Biosci. 2019;9(1):30. https://doi.org/10.1186/ s13578-019-0293-z.

39. Caicedo A, Aponte PM, Cabrera F, Hidalgo C, Khoury M. Artificial mitochondria transfer: current challenges, advances, and future applications. Stem Cells Int. 2017;2017:7610414-7610414. https://doi. org/10.1155/2017/7610414.

40. Paliwal S, Chaudhuri R, Agrawal A, Mohanty S. Regenerative abilities of mesenchymal stem cells through mitochondrial transfer. J Biomed Sci. 2018;25(1):31

41. Hsu Y-C, Wu Y-T, Yu T-H, Wei Y-H Mitochondria in mesenchymal stem cell biology and cell therapy: from cellular differentiation to mitochondrial transfer. In: Seminars in cell \& developmental biology, 2016. New York: Elsevier, pp 119-131

42. Rustom A, Saffrich R, Markovic I, Walther P, Gerdes H-HJS. Nanotubular highways for intercellular organelle transport. Science. 2004;303(5660):1007-100.

43. Gerdes $\mathrm{H}-\mathrm{H}$, Bukoreshtliev NV, Barroso J. Tunneling nanotubes: a new route for the exchange of components between animal cells. FEBS Lett. 2007:581(11):2194-201.

44. Davis DM, Sowinski S. Membrane nanotubes: dynamic long-distance connections between animal cells. Rev Mol Cell Biol. 2008;9(6):431.

45. Rogers RS, Bhattacharya JJP. When cells become organelle donors. Physiology. 2013;28(6):414-22.

46. Spees JL, Olson SD, Whitney MJ, Prockop D. Mitochondrial transfer between cells can rescue aerobic respiration. Proc Natl Acad Sci USA. 2006;103(5):1283-8.

47. Liu K, Ji K, Guo L, Wu W, Lu H, Shan P, Yan C, Mesenchymal stem cells rescue injured endothelial cells in an in vitro ischemia-reperfusion model via tunneling nanotube like structure-mediated mitochondrial transfer. Microvasc Res. 2014;92:10-8.

48. Berridge MV, McConnell MJ, Grasso C, Bajzikova M, Kovarova J, Neuzil J. Horizontal transfer of mitochondria between mammalian cells: beyond co-culture approaches. Curr Opin Genet Dev. 2016;38:75-82.
49. Patananan AN, Wu T-H, Chiou P-Y, Teitell MA. Modifying the mitochondrial genome. Cell Metab. 2016;23(5):785-96.

50. Moschoi R, Imbert V, Nebout M, Chiche J, Mary D, Prebet T, Saland E, Castellano R, Pouyet L, Collette Y. Protective mitochondrial transfer from bone marrow stromal cells to acute myeloid leukemic cells during chemotherapy. Blood. 2016;128(2):253-64.

51. Cho YM, Kim JH, Kim M, Park SJ, Koh SH, Ahn HS, Kang GH, Lee J-B, Park KS, Lee HK. Mesenchymal stem cells transfer mitochondria to the cells with virtually no mitochondrial function but not with pathogenic mtDNA mutations. PLoS ONE. 2012;7(3):e32778.

52. Wang $X$, Gerdes $\mathrm{H}-\mathrm{H}$. Transfer of mitochondria via tunneling nanotubes rescues apoptotic PC12 cells. Cell Death Differ. 2015;22(7):1181.

53. Islam MN, Das SR, Emin MT, Wei M, Sun L, Westphalen K, Rowlands DJ, Quadri SK, Bhattacharya S, Bhattacharya J. Mitochondrial transfer from bone-marrow-derived stromal cells to pulmonary alveoli protects against acute lung injury. Nat Med. 2012;18(5):759.

54. Ahmad T, Mukherjee S, Pattnaik B, Kumar M, Singh S, Rehman R, Tiwari BK, Jha KA, Barhanpurkar AP, Wani MR. Miro1 regulates intercellular mitochondrial transport \& enhances mesenchymal stem cell rescue efficacy. EMBO J. 2014;33(9):994-1010.

55. Tan AS, Baty JW, Dong L-F, Bezawork-Geleta A, Endaya B, Goodwin J, Bajzikova M, Kovarova J, Peterka M, Yan B. Mitochondrial genome acquisition restores respiratory function and tumorigenic potential of cancer cells without mitochondrial DNA. Cell Metab. 2015;21(1):81-94.

56. Pasquier J, Guerrouahen BS, Al Thawadi H, Ghiabi P, Maleki M, AbuKaoud N, Jacob A, Mirshahi M, Galas L, Rafii SJ. Preferential transfer of mitochondria from endothelial to cancer cells through tunneling nanotubes modulates chemoresistance. J Transl Med. 2013;11(1):94.

57. Bukoreshtliev NV, Wang X, Hodneland E, Gurke S, Barroso JF, Gerdes $\mathrm{H}-\mathrm{H}$. Selective block of tunneling nanotube (TNT) formation inhibits intercellular organelle transfer between PC12 cells. FEBS Lett. 2009;583(9):1481-8

58. Wang Y, Cui J, Sun $X$, Zhang Y. Tunneling-nanotube development in astrocytes depends on p53 activation. Cell Death Differ. 2011;18(4):732.

59. Lou E, Fujisawa S, Morozov A, Barlas A, Romin Y, Dogan Y, Gholami S Moreira AL, Manova-Todorova K, Moore MA. Tunneling nanotubes provide a unique conduit for intercellular transfer of cellular contents in human malignant pleural mesothelioma. PLoS ONE. 2012;7(3):e33093.

60. Sun X, Wang Y, Zhang J, Tu J, Wang X, Su X, Wang L, Zhang Y. Tunnelingnanotube direction determination in neurons and astrocytes. Cell Death Dis. 2012;3(12):e438.

61. Ralston KS, Solga MD, Mackey-Lawrence NM, Bhattacharya A, Petri WA Jr. Trogocytosis by Entamoeba histolytica contributes to cell killing and tissue invasion. Nature. 2014;508(7497):526.

62. Steele S, Radlinski L, Taft-Benz S, Brunton J, Kawula TH. Trogocytosisassociated cell to cell spread of intracellular bacterial pathogens. Elife. 2016:5:e10625.

63. Torralba D, Baixauli F, Sánchez-Madrid F. Mitochondria know no boundaries: mechanisms and functions of intercellular mitochondrial transfer. Front Cell Dev Biol. 2016;4:107.

64. Wada K-I, Hosokawa K, Ito Y, Maeda M. Quantitative control of mitochondria transfer between live single cells using a microfluidic device. Biol Open. 2017:6(12):1960-5.

65. Önfelt B, Nedvetzki S, Benninger RK, Purbhoo MA, Sowinski S, Hume AN, Seabra MC, Neil MA, French PM, Davis DMJT. Structurally distinct membrane nanotubes between human macrophages support long-distance vesicular traffic or surfing of bacteria. J Immunol. 2006;177(12):8476-83.

66. Benard M, Schapman D, Lebon A, Monterroso B, Bellenger M, Le Foll F, Pasquier J, Vaudry H, Vaudry D, Galas L. Structural and functional analysis of tunneling nanotubes (TnTs) using gCW STED and gconfocal approaches. Biol Cell. 2015;107(11):419-25.

67. Las G, Shirihai OS. Miro1: new wheels for transferring mitochondria. EMBO J. 2014;33(9):939-41.

68. Fransson Å, Ruusala A, Aspenström PJ. Atypical Rho GTPases have roles in mitochondrial homeostasis and apoptosis. J Biol Chem. 2003;278(8):6495-502.

69. Lu J, Zheng X, Li F, Yu Y, Chen Z, Liu Z, Wang Z, Xu H, Yang W. Tunneling nanotubes promote intercellular mitochondria transfer followed by increased invasiveness in bladder cancer cells. Oncotarget. 2017;8(9):15539. 
70. Snyder JP, Amiel E. Regulation of dendritic cell immune function and metabolism by cellular nutrient sensor mammalian target of rapamycin (mTOR). Front Immunol. 2019;9:3145.

71. Caicedo A, Fritz V, Brondello J-M, Ayala M, Dennemont I, Abdellaoui N, De Fraipont F, Moisan A, Prouteau CA, Boukhaddaoui H. MitoCeption as a new tool to assess the effects of mesenchymal stem/stromal cell mitochondria on cancer cell metabolism and function. Sci Rep. 2015;5:9073.

72. Zhang Y, Yu Z, Jiang D, Liang X, Liao S, Zhang Z, Yue W, Li X, Chiu S-M, Chai Y-H. iPSC-MSCs with high intrinsic MIRO1 and sensitivity to TNF-a yield efficacious mitochondrial transfer to rescue anthracyclineinduced cardiomyopathy. Stem Cell Reports. 2016;7(4):749-63.

73. Komen J, Thorburn DJB. Turn up the power-pharmacological activation of mitochondrial biogenesis in mouse models. J Pharmacol. 2014;171(8):1818-36.

74. Lin S, Liu M, Son YJ, Timothy Himes B, Snow DM, Yu W, Baas PW. Inhibition of Kinesin-5, a microtubule-based motor protein, as a strategy for enhancing regeneration of adult axons. Traffic. 2011;12(3):269-86.

75. Babenko VA, Silachev DN, Popkov VA, Zorova LD, Pevzner IB, Plotnikov EY, Sukhikh GT, Zorov DB. Miro1 enhances mitochondria transfer from multipotent mesenchymal stem cells (MMSC) to neural cells and improves the efficacy of cell recovery. Molecules. 2018;23(3):687.

76. Elliott $R$, Jiang $X$, Head J. Mitochondria organelle transplantation: introduction of normal epithelial mitochondria into human cancer cells inhibits proliferation and increases drug sensitivity. Breast Cancer Res Treat. 2012;136(2):347-54.

77. Vallabhaneni KC, Haller H, Dumler I. Vascular smooth muscle cells initiate proliferation of mesenchymal stem cells by mitochondrial transfer via tunneling nanotubes. Stem Cells Dev. 2012;21(17):3104-13.

78. Zhang Q, Raoof M, Chen Y, Sumi Y, Sursal T, Junger W, Brohi K, Itagaki $\mathrm{K}$, Hauser CJ. Circulating mitochondrial DAMPs cause inflammatory responses to injury. Nature. 2010;464(7285):104.

79. Weinberg SE, Sena LA, Chandel NS. Mitochondria in the regulation of innate and adaptive immunity. Immunity. 2015;42(3):406-17.

80. Oka T, Hikoso S, Yamaguchi O, Taneike M, Takeda T, Tamai T, Oyabu J, Murakawa T, Nakayama H, Nishida K. Mitochondrial DNA that escapes from autophagy causes inflammation and heart failure. Nature. 2012;485(7397):251.

81. Shimada K, Crother TR, Karlin J, Dagvadorj J, Chiba N, Chen S, Ramanujan VK, Wolf AJ, Vergnes L, Ojcius DM. Oxidized mitochondrial DNA activates the NLRP3 inflammasome during apoptosis. Immunity. 2012;36(3):401-14.

82. Collins LV, Hajizadeh S, Holme E, Jonsson IM, Tarkowski AJ. Endogenously oxidized mitochondrial DNA induces in vivo and in vitro inflammatory responses. J Leukoc Biol. 2004;75(6):995-1000.

83. Chung-ha OD, Kim K-Y, Bushong EA, Mills EA, Boassa D, Shih T, Kinebuchi M, Phan S, Zhou Y, Bihlmeyer NA. Transcellular degradation of axonal mitochondria. Proc Natl Acad Sci USA. 2014;111(26):9633-8.

84. Yi Y-C, Chen M-J, Ho JY-P, Guu H-F, Ho ES-CJ. Mitochondria transfer can enhance the murine embryo development. J Assist Reprod Genet. 2007;24(10):445-9.

85. Yamada M, Emmanuele V, Sanchez-Quintero MJ, Sun B, Lallos G, Paull D, Zimmer M, Pagett S, Prosser RW, Sauer MV. Genetic drift can compromise mitochondrial replacement by nuclear transfer in human oocytes. Cell Stem Cell. 2016;18(6):749-54.

86. Morrison TJ, Jackson MV, Cunningham EK, Kissenpfennig A, McAuley DF, O'Kane CM, Krasnodembskaya AD. Mesenchymal stromal cells modulate macrophages in clinically relevant lung injury models by extracellular vesicle mitochondrial transfer. Am J Respir Crit Care Med. 2017;196(10):1275-86

87. Jackson MV, Morrison TJ, Doherty DF, McAuley DF, Matthay MA, Kissenpfennig A, O'Kane CM, Krasnodembskaya AD. Mitochondrial transfer via tunneling nanotubes is an important mechanism by which mesenchymal stem cells enhance macrophage phagocytosis in the in vitro and in vivo models of ARDS. Stem Cells. 2016;34(8):2210-23.

88. Guo R, Davis D, Fang Y. Intercellular transfer of mitochondria rescues virus-induced cell death but facilitates cell-to-cell spreading of porcine reproductive and respiratory syndrome virus. Virology. 2018;517:122-34.

89. Naji A, Suganuma N, Espagnolle N, Ki Y, Baba N, Sensebé L, Deschaseaux F. Rationale for determining the functional potency of mesenchymal stem cells in preventing regulated cell death for therapeutic use. Stem Cells Transl Med. 2017;6(3):713-9.

90. Kong D, Zhu J, Liu Q, Jiang Y, Xu L, Luo N, Zhao Z, Zhai Q, Zhang H, Zhu M. Mesenchymal stem cells protect neurons against hypoxic-ischemic injury via inhibiting parthanatos, necroptosis, and apoptosis, but not autophagy. Cell Mol Neurobiol. 2017;37(2):303-13.

91. Chen GY, Nuñez G. Sterile inflammation: sensing and reacting to damage. Nat Rev Immunol. 2010;10(12):826.

92. Naji A, Muzembo BA, Yagyu K-I, Baba N, Deschaseaux F, Sensebé L, Suganuma N. Endocytosis of indium-tin-oxide nanoparticles by macrophages provokes pyroptosis requiring NLRP3-ASC-Caspase 1 axis that can be prevented by mesenchymal stem cells. Sci Rep. 2016;6:26162.

93. Cselenyák A, Pankotai E, Horváth EM, Kiss L, Lacza Z. Mesenchymal stem cells rescue cardiomyoblasts from cell death in an in vitro ischemia model via direct cell-to-cell connections. BMC Cell Biol. 2010;11(1):29.

94. Li X, Zhang Y, Yeung SC, Liang Y, Liang X, Ding Y, Ip MS, Tse H-F, Mak JC, Lian Q. Mitochondrial transfer of induced pluripotent stem cell-derived mesenchymal stem cells to airway epithelial cells attenuates cigarette smoke-induced damage. Am J Respir Cell Mol Biol. 2014;51(3):455-65.

95. Wang J, Li H, Yao Y, Zhao T, Chen Y-y, Shen Y-I, Wang L-I, Zhu Y. Stem cell-derived mitochondria transplantation: a novel strategy and the challenges for the treatment of tissue injury. Stem Cell Res Ther. 2018;9(1):106

96. Mahrouf-Yorgov M, Augeul L, Da Silva CC, Jourdan M, Rigolet M, Manin S, Ferrera R, Ovize M, Henry A, Guguin AJ. Mesenchymal stem cells sense mitochondria released from damaged cells as danger signals to activate their rescue properties. Cell Death Differ. 2017;24(7):1224.

97. Chen J, Wang Q, Feng X, Zhang Z, Geng L, Xu T, Wang D, Sun L. Umbilical cord-derived mesenchymal stem cells suppress autophagy of $T$ cells in patients with systemic lupus erythematosus via transfer of mitochondria. Stem Cells Int. 2016;2016:4062789.

98. Sinclair KA, Yerkovich ST, Hopkins PM-A, Chambers DC. Characterization of intercellular communication and mitochondrial donation by mesenchymal stromal cells derived from the human lung. Stem Cell Res Ther. 2016:7(1):91.

99. Önfelt B, Nedvetzki S, Yanagi K, Davis DM. Cutting edge: Membrane nanotubes connect immune cells. J Immunol. 2004;173(3):1511-3.

100. Hase K, Kimura S, Takatsu H, Ohmae M, Kawano S, Kitamura H, Ito M, Watarai H, Hazelett CC, Yeaman CJ. M-Sec promotes membrane nanotube formation by interacting with Ral and the exocyst complex. Nat Cell Biol. 2009;11(12):1427.

101. Jiang D, Gao F, Zhang Y, Wong DSH, Li Q, Tse H-f, Xu G, Yu Z, Lian QJ. Mitochondrial transfer of mesenchymal stem cells effectively protects corneal epithelial cells from mitochondrial damage. Cell Death Dis. 2016;7(11):e2467

102. Pekkurnaz G, Trinidad JC, Wang X, Kong D, Schwarz TL. Glucose regulates mitochondrial motility via Milton modification by O-GICNAC transferase. Cell. 2014;158(1):54-68.

103. Thayanithy V, Dickson EL, Steer C, Subramanian S, Lou E. Tumor-stromal cross talk: direct cell-to-cell transfer of oncogenic microRNAs via tunneling nanotubes. Transl Res. 2014;164(5):359-65.

104. Eugenin EA, Gaskill PJ, Berman JW. Tunneling nanotubes (TNT) a potential mechanism for intercellular trafficking. Commun Integr Biol. 2009;2(3):243-4.

105. Domhan S, Ma L, Tai A, Anaya Z, Beheshti A, Zeier M, Hlatky L, Abdollahi A. Intercellular communication by exchange of cytoplasmic material via tunneling nano-tube like structures in primary human renal epithelial cells. PLOS ONE. 2011;6(6):e21283.

106. Boukelmoune N, Chiu GS, Kavelaars A, Heijnen CJ. Mitochondrial transfer from mesenchymal stem cells to neural stem cells protects against the neurotoxic effects of cisplatin. Acta Neuropathol Commun. 2018;6(1):139.

107. Stowers RS, Megeath LJ, Górska-Andrzejak J, Meinertzhagen IA, Schwarz TL. Axonal transport of mitochondria to synapses depends on milton, a novel Drosophila protein. Neuron. 2002;36(6):1063-77.

108. Glater EE, Megeath LJ, Stowers RS, Schwarz TL. Axonal transport of mitochondria requires milton to recruit kinesin heavy chain and is light chain independent. J Cell Biol. 2006;173(4):545-57.

109. Bohil AB, Robertson BW, Cheney RE. Myosin-X is a molecular motor that functions in filopodia formation. Proc Natl Acad Sci USA. 2006;103(33):12411-6. 
110. Nawaz M, Fatima F. Extracellular vesicles, tunneling nanotubes, and cellular interplay: synergies and missing links. Front Mol Biosci. 2017;4:50.

111. Nakada K, Inoue K, Ono T, Isobe K, Ogura A, Goto Y-I, Nonaka I, Hayashi J-I. Inter-mitochondrial complementation: mitochondria-specific system preventing mice from expression of disease phenotypes by mutant mtDNA. Nat Med. 2001;7(8):934.

112. Ono T, Isobe K, Nakada K, Hayashi J-I. Human cells are protected from mitochondrial dysfunction by complementation of DNA products in fused mitochondria. Nat Genet. 2001;28(3):272.

113. Aguilar PS, Baylies MK, Fleissner A, Helming L, Inoue N, Podbilewicz B, Wang $\mathrm{H}$, Wong M. Genetic basis of cell-cell fusion mechanisms. Trends Genet. 2013;29(7):427-37.

114. Eura Y, Ishihara N, Yokota S, Mihara K. Two mitofusin proteins, mammalian homologues of $\mathrm{FZO}$, with distinct functions are both required for mitochondrial fusion. J Biochem. 2003;134(3):333-44.

115. Spees JL, Lee RH, Gregory CA. Mechanisms of mesenchymal stem/stromal cell function. Stem Cell Res Ther. 2016;7(1):125.

116. Raposo G, StoorvogelW. Extracellular vesicles: exosomes, microvesicles, and friends. J Cell Biol. 2013;200(4):373-83.

117. Lai RC, Tan SS, Yeo RWY, Choo ABH, Reiner AT, SuY, Shen Y, Fu Z, Alexander L, Sze SK. MSC secretes at least 3 EV types each with a unique permutation of membrane lipid, protein and RNA. J Extracell Vesicles. 2016;5(1):29828.

118. Crescitelli R, Lässer C, Szabó TG, Kittel A, Eldh M, Dianzani I, Buzás El, Lötvall J. Distinct RNA profiles in subpopulations of extracellular vesicles: apoptotic bodies, microvesicles and exosomes. J Extracell Vesicles. 2013;2(1):20677.

119. Goldie BJ, Dun MD, Lin M, Smith ND, Verrills NM, Dayas CV, Cairns MJ. Activityassociated miRNA are packaged in Map1b-enriched exosomes released from depolarized neurons. Nucleic Acids Res. 2014;42(14):9195-208.

120. Davis ME. Exosomes: What do we love so much about them? Circ Res. 2016;1 19(12):1280-2.

121. Sansone P, Savini C, Kurelac I, Chang Q, Amato LB, Strillacci A, Stepanova A, Iommarini L, Mastroleo C, Daly L, Galkin A, Thakur BK, Soplop N, Uryu K, Hoshino A, Norton L, Bonafé M, Cricca M, Gasparre G, Lyden D, Bromberg J. Packaging and transfer of mitochondrial DNA via exosomes regulate escape from dormancy in hormonal therapy-resistant breast cancer. Proc Natl Acad Sci USA. 2017;114(43):E9066. https://doi.org/10.1073/ pnas. 1704862114.

122. Islam MN, Das SR, Emin MT, Wei M, Sun L, Westphalen K, Rowlands DJ, Quadri SK, Bhattacharya S, Bhattacharya J. Mitochondrial transfer from bonemarrow-derived stromal cells to pulmonary alveoli protects against acute lung injury. Nature Med. 2012;18(5):759.

123. Yáñez-Mó M, Siljander PR-M, Andreu Z, Bedina Zavec A, Borràs FE, Buzas El, Buzas K, Casal E, Cappello F, Carvalho J. Biological properties of extracellular vesicles and their physiological functions. J Extracell Vesicles. 2015:4(1):27066.

124. Zhang Y, Liang $X$, Lian $Q$, Tse HF. Perspective and challenges of mesenchymal stem cells for cardiovascular regeneration. Expert Rev Cardiovasc Ther. 2013;11(4):505-17. https://doi.org/10.1586/erc.13.5.

125. Amini H, Rezaie J, Vosoughi A, Rahbarghazi R, Nouri M. Cardiac progenitor cells application in cardiovascular disease. J Cardiovasc Thorac Res. 2017;9(3):127.

126. Zuo S, Jones WK, Li H, He Z, Pasha Z, Yang Y, Wang Y, Fan G-C, Ashraf M, Xu M. Paracrine effect of Wnt11-overexpressing mesenchymal stem cells on ischemic injury. Stem Cells Dev. 2012;21(4):598-608.

127. Siu C-W, Liao S-Y, Liu Y, Lian Q, Tse H-F. Stem cells for myocardial repair. Thromb Haemost. 2010;104(07):6-12. https://doi.org/10.1160/ th09-05-0336.

128. Gnecchi M, He H, Liang OD, Melo LG, Morello F, Mu H, Noiseux N, Zhang L, Pratt RE, Ingwall JS, Dzau VJ. Paracrine action accounts for marked protection of ischemic heart by Akt-modified mesenchymal stem cells. Nat Med. 2005;11(4):367-8. https://doi.org/10.1038/nm0405-367.

129. Acquistapace A, Bru T, Lesault PF, Figeac F, Coudert AE, Le Coz O, Christov C, Baudin X, Auber F, Yiou R. Human mesenchymal stem cells reprogram adult cardiomyocytes toward a progenitor-like state through partial cell fusion and mitochondria transfer. Stem Cells. 2011;29(5):812-24.

130. Jiang D, Xiong G, Feng H, Zhang Z, Chen P, Yan B, Chen L, Gandhervin K, Ma C, Li C, Han S, Zhang Y, Liao C, Lee T-L, Tse H-F, Fu Q-L, Chiu K, Lian Q. Donation of mitochondria by iPSC-derived mesenchymal stem cells protects retinal ganglion cells against mitochondrial complex I defect-induced degeneration. Theranostics. 2019;9(8):2395-410. https://doi.org/10.7150/ thno.29422.
131. Court AC, Le-Gatt A, Luz-Crawford P, Parra E, Aliaga-Tobar V, Bátiz LF, Contreras RA, Ortúzar MI, Kurte M, Elizondo-Vega R, Maracaja-Coutinho V, Pino-Lagos K, Figueroa FE, Khoury M. Mitochondrial transfer from MSCs to $T$ cells induces Treg differentiation and restricts inflammatory response. EMBO Rep. 2020;21 (2):e48052. https://doi.org/10.15252/embr.201948052.

132. Emani SM, Piekarski BL, Harrild D, Pedro J, McCully JD. Autologous mitochondrial transplantation for dysfunction after ischemia-reperfusion injury. J Thorac Cardiovasc Surg. 2017;154(1):286-9.

133. Koyanagi M, Brandes RP, Haendeler J, Zeiher AM, Dimmeler S. Cell-to-cell connection of endothelial progenitor cells with cardiac myocytes by nanotubes: a novel mechanism for cell fate changes? Circ Res. 2005;96(10):1039-41.

134. Yang H, Borg TK, Ma Z, Xu M, Wetzel G, Saraf LV, Markwald R, Runyan RB, Gao BZ. Biochip-based study of unidirectional mitochondrial transfer from stem cells to myocytes via tunneling nanotubes. Biofabrication. 2016;8(1):015012.

135. Cowan DB, Yao R, Akurathi V, Snay ER, Thedsanamoorthy JK, Zurakowski D, Ericsson M, Friehs I, Wu Y, Levitsky S. Intracoronary delivery of mitochondria to the ischemic heart for cardioprotection. PLOS ONE. 2016;11(8):e0160889.

136. Pacak CA, Preble JM, Kondo H, Seibel P, Levitsky S, Pedro J, Cowan DB, McCully JD. Actin-dependent mitochondrial internalization in cardiomyocytes: evidence for rescue of mitochondrial function. Biol Open. 2015:4(5):622-6.

137. Baudino TA, McFadden A, Fix C, Hastings J, Price R, Borg TK. Cell patterning: interaction of cardiac myocytes and fibroblasts in three-dimensional culture. Microsc Microanal. 2008;14(2):117-25.

138. Porter KE, Turner NA. Cardiac fibroblasts: at the heart of myocardial remodeling. Pharmacol Ther. 2009;123(2):255-78.

139. Pfeiffer E, Wright A, Edwards A, Stowe J, McNall K, Tan J, Niesman I, Patel $H$, Roth D, Omens JJ. Caveolae in ventricular myocytes are required for stretch-dependent conduction slowing. J Mol Cell Cardiol. 2014;76:265-74.

140. Kitani T, Kami D, Matoba S, Gojo S. Internalization of isolated functional mitochondria: involvement of macropinocytosis. J Cell Mol Med. 2014;18(8):1694-703.

141. Huang $X$, Sun L, Ji S, Zhao T, Zhang W, Xu J, Zhang J, Wang Y, Wang $X$, Franzini-Armstrong C. Kissing and nanotunneling mediate intermitochondrial communication in the heart. Proc Natl Acad Sci USA. 2013;110(8):2846-51.

142. Plotnikov E, Khryapenkova T, Vasileva A, Marey M, Galkina S, Isaev N, Sheval E, Polyakov V, Sukhikh G, Zorov DB. Cell-to-cell cross-talk between mesenchymal stem cells and cardiomyocytes in co-culture. J Cell Mol Med. 2008;12(5a):1622-31.

143. Driesen RB, Dispersyn GD, Verheyen FK, van den Eijnde SM, Hofstra L, Thoné F, Dijkstra P, Debie W, Borgers M, Ramaekers FC. Partial cell fusion: a newly recognized type of communication between dedifferentiating cardiomyocytes and fibroblasts. Cardiovasc Res. 2005;68(1):37-46.

144. Plotnikov EY, Khryapenkova TG, Galkina SI, Sukhikh GT, Zorov DB. Cytoplasm and organelle transfer between mesenchymal multipotent stromal cells and renal tubular cells in co-culture. Exp Cell Res. 2010;316(15):2447-555.

145. Dixon IM, Davies JJ. Fibroblasts are coupled to myocytes in heart muscle by nanotubes: a bigger and better syncytium? Cardiovasc Res. 2011;92(1):5-6.

146. Ma Z, Yang H, Liu H, Xu M, Runyan RB, Eisenberg CA, Markwald RR, Borg TK, Gao BZ. Mesenchymal stem cell-cardiomyocyte interactions under defined contact modes on laser-patterned biochips. PLOS ONE. 2013;8(2):e56554

147. Shen J, Zhang J-H, Xiao H, Wu J-M, He K-M, Lv Z-Z, Li Z-J, Xu M, Zhang Y-Y. Mitochondria are transported along microtubules in membrane nanotubes to rescue distressed cardiomyocytes from apoptosis. Cell Death Dis. 2018;9(2):81.

148. Yao Y, Fan X-L, Jiang D, Zhang Y, Li X, Xu Z-B, Fang S-B, Chiu S, Tse H-F, Lian Q. Connexin 43-mediated mitochondrial transfer of iPSC-MSCs alleviates asthma inflammation. Stem Cell Reports. 2018;11(5):1120-35.

\section{Publisher's Note}

Springer Nature remains neutral with regard to jurisdictional claims in published maps and institutional affiliations. 